\title{
Experimental studies on particle emissions from cruising ship, their characteristic properties, transformation and atmospheric lifetime in the marine boundary layer
}

\author{
A. Petzold ${ }^{1}$, J. Hasselbach ${ }^{1}$, P. Lauer ${ }^{2}$, R. Baumann ${ }^{1}$, K. Franke ${ }^{3}$, C. Gurk ${ }^{4}$, H. Schlager ${ }^{1}$, and E. Weingartner ${ }^{5}$ \\ ${ }^{1}$ Dt. Zentrum für Luft- und Raumfahrt, Inst. für Physik der Atmosphäre, Oberpfaffenhofen, 82234 Wessling, Germany \\ ${ }^{2}$ MAN Diesel SE, Stadtbachstr. 1, 86135 Augsburg, Germany \\ ${ }^{3}$ Institute for Environmental Physics, University of Bremen, Otto-Hahn-Allee 1, 28359 Bremen, Germany \\ ${ }^{4}$ Max-Planck-Institute for Chemistry, Johann-Joachim-Becher-Weg 27, 55128 Mainz, Germany \\ ${ }^{5}$ Laboratory of Atmospheric Chemistry, Paul Scherrer Institute, CH-5232 Villigen PSI, Switzerland
}

Received: 9 October 2007 - Published in Atmos. Chem. Phys. Discuss.: 19 October 2007

Revised: 17 March 2008 - Accepted: 15 April 2008 - Published: 6 May 2008

\begin{abstract}
Particle emissions from ship engines and their atmospheric transformation in the marine boundary layer (MBL) were investigated in engine test bed studies and in airborne measurements of expanding ship plumes. During the test rig studies, detailed aerosol microphysical and chemical properties were measured in the exhaust gas of a serial MAN B\&W seven-cylinder four-stroke marine diesel engine under various load conditions. The emission studies were complemented by airborne aerosol transformation studies in the plume of a large container ship in the English Channel using the DLR aircraft Falcon 20 E-5. Observations from emission studies and plume studies combined with a Gaussian plume dispersion model yield a consistent picture of particle transformation processes from emission to atmospheric processing during plume expansion. Particulate matter emission indices obtained from plume measurements are $8.8 \pm 1.0 \times 10^{15}(\mathrm{~kg} \text { fuel })^{-1}$ by number for non-volatile particles and $174 \pm 43 \mathrm{mg}$ (kg fuel $)^{-1}$ by mass for Black Carbon (BC). Values determined for test rig conditions between 85 and $110 \%$ engine load are of similar magnitude. For the total particle number including volatile compounds no emission index can be derived since the volatile aerosol fraction is subject to rapid transformation processes in the plume. Ship exhaust particles occur in the size range $D_{p}<0.3 \mu \mathrm{m}$, showing a bi-modal structure. The combustion particle mode is centred at modal diameters of $0.05 \mu \mathrm{m}$ for raw emissions to $0.10 \mu \mathrm{m}$ at a plume age of $1 \mathrm{~h}$. The smaller-sized volatile particle mode is centred at $D_{p} \leq 0.02 \mu \mathrm{m}$. From the decay of
\end{abstract}

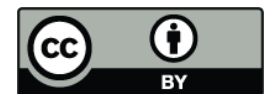

Correspondence to: A. Petzold (andreas.petzold@dlr.de) ship exhaust particle number concentrations in an expanding plume, a maximum plume life time of approx. $24 \mathrm{~h}$ is estimated for a well-mixed marine boundary layer.

\section{Introduction}

Shipping represents a major contribution to the international transportation sector which, however, is not well quantified in terms of global emissions and climate impacts. In this context, gaseous and particulate matter emissions from seagoing ship are gaining increasing attention because of likely environmental and climate effects (Corbett and Fischbeck, 1997; Capaldo et al., 1999; Lawrence and Crutzen, 1999; Endresen et al. 2003; Eyring et al., 2005a, b, 2007). Even from satellites, main shipping routes were detectable from their increased $\mathrm{NO}_{2}$ level (Beirle et al., 2004). Those emitted species may have a significant impact on the atmospheric composition and on air quality, and in particular on the ozone chemistry in the troposphere.

As for any combustion source, ship engines also emit particulate matter. Ship engine exhaust aerosol is composed of combustion aerosol particles consisting of elemental and organic carbon, sulphate and ash (Cooper, 2003; Petzold et al., 2004; Kasper et al., 2007), and of volatile particles forming from sulphuric acid in the expanding plume (Song et al., 2003; Gopalakrishnan et al., 2005; Chen et al., 2005; Petzold et al., 2007). Elemental or black carbon (BC) as one of the most efficient particulate absorbers of solar radiation and sulphuric acid particles as the major light-scattering aerosol fraction are the two exhaust components of highest relevance (Capaldo et al., 1999). Both constituents are expected to

Published by Copernicus Publications on behalf of the European Geosciences Union. 
have a strong impact on the atmospheric radiation budget. The magnitude of any resulting direct climate impact of $\mathrm{BC}$ emitted from ship traffic as well as the properties of particles emitted by cruising ships and their fate in the marine environment are not well known.

Beyond the direct effects of the emitted particles on Earth's radiation budget, these particles may act as cloud condensation nuclei $(\mathrm{CCN})$ and thus may increase the concentration of cloud droplets, which in turn modifies life cycle and radiative properties of marine stratiform clouds at the top of the MBL (Durkee et al., 2000a, b). In the detailed Monterey Area Ship Track Experiment MAST (Durkee et al., 2000a, b and references given there; Frick and Hoppel, 2000; Hobbs et al., 2000; Noone et al., 2000) the influence of particulate emissions from cruising ships on marine stratiform clouds and the formation of so-called ship tracks in the marine stratus deck were extensively studied. Beyond the local scale close to the emitting ship, first evidence of a larger-scale impact of ship emissions on cloud albedo and cloud top temperature of marine clouds is recently reported from satellite data analyses (Devasthale et al., 2006). Based on the analysis of AVHRR data, the authors show that over areas with high shipping frequency, a statistically significant increase in cloud albedo is found. Thus, ship emissions are likely to impact the atmosphere even on a larger scale than expected so far.

In contrast to the increasing interest on particle emissions from international shipping (Corbett, 2003), detailed chemical composition and aerosol microphysical data as well as data on aerosol transformation processes in the plume are sparse. Before we describe the scope of our study which aims at filling some of the existing gaps, we briefly summarise the current knowledge on the properties and fate of particle emissions from ship engines.

Current emission data originate from few engine studies using engine test rigs (Lyyränen et al., 1999, 2002; Petzold et al., 2004; Kasper et al., 2007), or sampling from auxiliary engines of ships at berth (Cooper, 2003). Aerosol properties in ship plumes were investigated in-situ during MAST by instrumented airship (Frick and Hoppel, 2000) or aircraft (Hobbs et al., 2000; Osborne et al., 2001), and during plume studies in the southern Atlantic Ocean (Sinha et al., 2003), as part of the NOAA International Transport and Chemical Transformation (ITCT) 2K2 airborne field campaign (Chen et al., 2005), and during the New England Air Quality Studies in 2002 and 2004 (Williams et al., 2005).

Total particulate matter emission factors for cruising ship in terms of particle number per $\mathrm{kg}$ of burnt fuel are $1.2-$

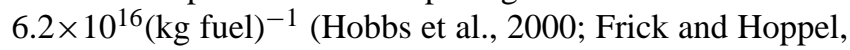
2000; Sinha et al., 2003; Chen et al., 2005). For accumulation mode particles with $D_{p}>0.1 \mu \mathrm{m}$, an emission factor of $0.1-0.5 \times 10^{16}(\mathrm{~kg} \text { fuel })^{-1}$ is reported by Sinha et al. (2003). The only test rig emission factors reported so far for total particles are $1-8 \times 10^{15} \mathrm{kWh}^{-1}$ at $100 \%$ engine load for a twostroke marine diesel engine of type Wärtsilä 4RTX-3 (Kasper et al., 2007). Although, the conversion to (kg fuel $)^{-1}$ is not available for this data set, we can estimate a range of emission factors of $5 \times 10^{15}-4 \times 10^{16}(\mathrm{~kg} \text { fuel })^{-1}$ by applying the average ratio of $0.212 \mathrm{~kg}$ fuel $/ \mathrm{kWh}$ (Eyring et al., 2005a). The fleet-average specific fuel oil consumption was derived from a set of 50 sample engines of different types, which included engines of the investigated type but also two-stroke marine diesel engines (Köhler 2002, 2003). The only available emission factor for $\mathrm{BC}$ mass emissions from cruising ship is $180 \pm 20 \mathrm{mg} \mathrm{BC}(\mathrm{kg} \text { fuel })^{-1}$ (Sinha et al., 2003).

Size distributions covering the entire nucleation to coarse mode size range $(0.005-3 \mu \mathrm{m}$ in diameter) are available for plumes embedded in the MBL (Frick and Hoppel, 2000; Hobbs et al., 2000; Petzold et al., 2004) and for fresh emissions (Lyyränen et al., 1999; Kasper et al., 2007). In fresh exhaust at full engine load, particle number size distributions are characterised by a bi-modal structure with modal diameters of $0.04-0.05 \mu \mathrm{m}$ (two-stroke engine: Kasper et al., 2007) and 0.04-0.06 $\mu \mathrm{m}$ (four-stroke engine: Lyyränen et al., 1999) for the main particle mode. For the two-stroke engine, a second but weaker mode is found at modal diameters $>0.1 \mu \mathrm{m}$. The application of a thermodenuder for the removal of volatile particles (Burtscher et al., 2001) reduces the number of particles by a factor of 10 (Kasper et al., 2007). Information on particle volatility and size distributions for $D_{p}>0.1 \mu \mathrm{m}$ are not reported in literature for four-stroke diesel engines.

Inside ship plumes embedded in the cloud-free MBL, particle size distributions show a broad mode at $0.06-0.1 \mu \mathrm{m}$ (Hobbs et al., 2000; Frick and Hoppel, 2000). Particles larger than $0.2 \mu \mathrm{m}$ contribute less than $5 \%$ by number. Almost no data exist on the modification of aerosol size distributions during plume expansion and dispersion, although the nonvolatile accumulation mode fraction is most important for ship track formation (Frick and Hoppel, 2000; Dusek et al., 2006). The only available source (Osborne et al., 2001) provides size distribution data limited to the accumulation mode size range with $D_{p}>0.10 \mu \mathrm{m}$.

Whereas the engine emission studies provide emission factors for particulate matter in terms of number and mass, they do not go into details of the chemical composition which, however, is needed for modelling the CCN activation process. The airborne studies in ship plumes again focus on emission factors, while size distribution information is reported only to a limited extent. Particle size distributions, however, reflect the aerosol transformation process from emission to $\mathrm{CCN}$ activation. Both objectives are tackled in the presented study.

Airborne aerosol transformation studies in the marine boundary layer were conducted as part of the ICARTT-ITOP (Intercontinental Transport of Ozone and Precursors) experiment in 2004 using the DLR aircraft Falcon 20 E-5. Ship emission studies were conducted in 2006 as part of the European Integrated Project HERCULES (High Efficiency $R \& D$ on Combustion with Ultra Low Emissions for Ships). We 
analysed the whole data set with respect to emission factors for black carbon mass and particle number, chemical speciation, aerosol transformation in an expanding plume and to an estimate for plume and particle life times in the MBL. For the first time, emission and plume data gathered with similar instrumentation are combined in such a study.

\section{Methods}

\subsection{Test rig studies}

In the framework of HERCULES particle emissions from a serial MAN B\&W four-stroke marine diesel engine were studied at the engine manufacturer's test facilities in Augsburg, Germany. The engine was operated at various load conditions between $10 \%$ and $100 \%$, running on heavy fuel oil (HFO) with a sulphur content of 2.21 weight-\% (wt-\%). Detailed aerosol microphysics and chemistry were measured including aerosol number and size distribution for total exhaust aerosol and non-volatile combustion particles from online measurements, and chemical composition in terms of total particulate mass (PM), elemental carbon (EC), organic matter (OM), and sulphate from bulk filter samples.

The applied instrumentation consisted of three Condensation Particle Counters (CPC, TSI 3010/3760A), one Differential Mobility Analyser (DMA, TSI 3071), and a MultiAngle Absorption Photometer MAAP (Thermo Instruments Model 5012; Petzold and Schönlinner, 2004) for black carbon monitoring. The CPC were partially equipped with Diffusion Screen Separators consisting of $n_{D S}$ screens (Feldpausch et al., 2006) which yielded lower cut-off diameters of $0.01 \mu \mathrm{m}\left(\mathrm{CPC} \# 1, n_{D S}=0\right), 0.03 \mu \mathrm{m}\left(\mathrm{CPC} \# 2, n_{D S}=3\right)$, and $0.08 \mu \mathrm{m}\left(\mathrm{CPC} 33, n_{D S}=10\right)$. Separation of volatile and nonvolatile aerosol compounds was achieved by a thermodenuder (Burtscher et al. 2001). The samples for the on-line aerosol microphysics were diluted by a factor of $10^{5}$ using a set of isokinetic dilution stages Model VKL-10 (Palas, Karlsruhe, Germany). The dilution was monitored by simultaneous measurements of the $\mathrm{CO}_{2}$ mixing ratio in the dilution air and in the diluted exhaust gas sample after the first set of dilution stages. The sample lines were kept at $150^{\circ} \mathrm{C}$ up to the first dilutor. The first dilutor was operated with heated dilution air in order to prevent condensation of water vapour. The subsequent dilutors were operated with dry and particlefree air at ambient temperature. The measurement set-up for the test rig studies is shown in Fig. 1.

Filter stack samples were taken with an AVL 472 Smart Sampler Modular dilution system. Teflon filters were analysed by gravimetry for total mass, pre-conditioned quartz filters were analysed by a multi-step combustion method for organic (OC) and elemental (EC) carbon (VDI guideline 24652, 2005; Schmid et al., 2001) and by ion chromatography for sulphate. Prior to thermal analysis, the extractable organic carbon fraction was removed in a solvent mixture of toluol

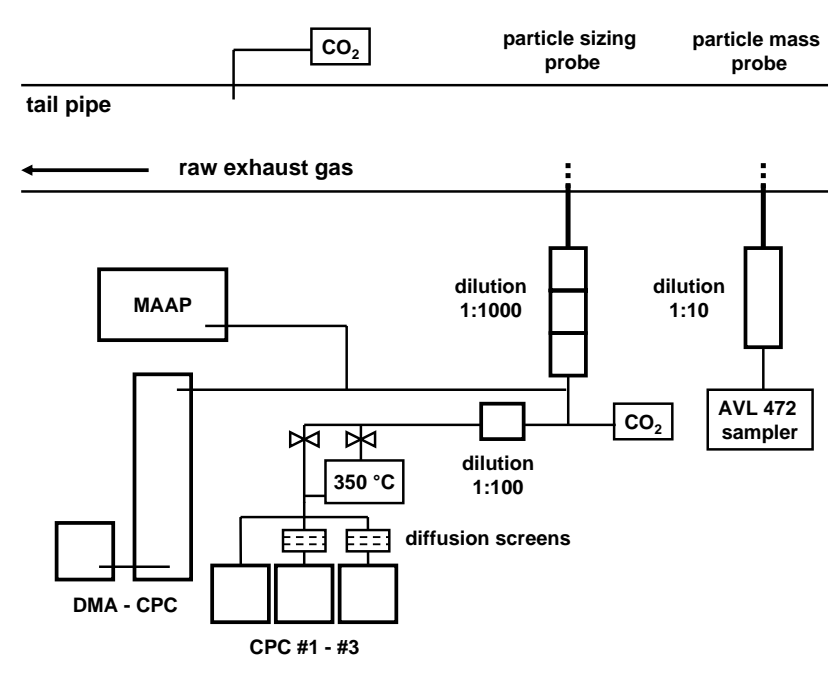

Fig. 1. Instrumental set-up during the test rig studies.

and isopropanol. In the first step of the multi-step combustion method, the filter sample was heated to $550^{\circ} \mathrm{C}$ in a nitrogen flow to volatilise organic carbon which was subsequently oxidised to $\mathrm{CO}_{2}$ by copper oxide and measured by infrared absorption. In a second step the residual carbon on the filter sample was oxidised in oxygen airflow at $650^{\circ} \mathrm{C}$ and detected as $\mathrm{CO}_{2}$. Step \#1 provided OC, step \#2 provided EC. Organic matter $(\mathrm{OM})$ was calculated from organic carbon via the relationship $\mathrm{OM}=1.2 \times \mathrm{OC}$, and sulphate-bound water was calculated from the average relationship of bound $\mathrm{H}_{2} \mathrm{O}=0.8 \times \mathrm{SO}_{4}$ for engine test conditions (Ulrich, 1994).

The correlation of the sulphate bound water of $\mathrm{H}_{2} \mathrm{O}=0.8 \times \mathrm{SO}_{4}$ is based on experimental data obtained from heavy duty diesel engine emissions. The relationship was determined from the analysis of filter samples which were weighted under well-defined conditions of $40 \%$ relative humidity and $293 \mathrm{~K}$ air temperature. The rationale behind the correlation $\mathrm{OM}=1.2 \times \mathrm{OC}$ is based on the average composition of diesel fuel which is assumed to consist of $52 \%-70 \%$ of paraffines, $11 \%$ of oxygenated hydrocarbons, $10 \%$ of organic acids and $7 \%$ of aromatic compounds. The assumed OM/OC ratios are 1.18 (paraffines), 1.23 (oxygenated HC), 1.30 (organic acids), and 1.08 (aromatic $\mathrm{HC}$ ). The weighted average ratio of OM to OC is 1.20.

An extensive presentation of the test rig data is beyond the scope of this study and will be published elsewhere. Here, we focus on the emission factors in terms of EC, and of particle number and size for total as well as for non-volatile particles. Engine load conditions of $85 \%-110 \%$ were considered because they include typical operation conditions for ships at cruise. Particle size distributions measured by means of a DMA are compared to chemical analyses of the key components EC, OM, sulphates and ash. The chemical composition and size distribution data measured for emission conditions cannot be related quantitatively to plume data obtained from 


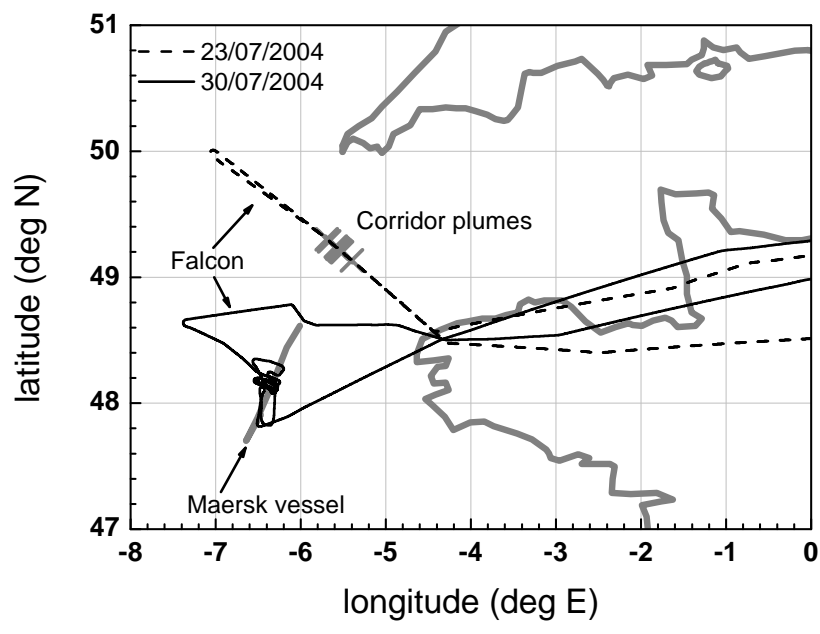

Fig. 2. Falcon flight tracks for the ship corridor survey flight on 23 July 2004 and the single plume study on 30 July 2004. Short gray bars indicate aged ship plumes in the English Channel, young ship plume encounters were met along the indicated sailing route of the MAERSK vessel (thick gray line).

airborne measurements. However, conclusions on the chemical key components of aerosol modes identified in the plume can be drawn.

\subsection{Airborne measurements}

In the course of the ICARTT-ITOP experiment in 2004, the DLR research aircraft Falcon was used to study fresh and aged ship plumes at the exit of the English Channel towards the Gulf of Biscay. The ship plume studies consisted of two different parts. On 23 July 2004, a ship corridor survey flight was conducted which traversed the English Channel perpendicular to the major ship routes at a constant altitude of $300 \mathrm{~m}$ above sea level (a.s.l.). On 30 July 2004, a single plume of a large container ship operated by the MAERSK shipping company was extensively studied. Figure 2 shows the respective Falcon flight tracks with ship plume encounters inserted. In both cases no ship tracks have formed.

On board the DLR Falcon, a comprehensive set of instruments was operated for the in situ measurement of aerosol microphysical properties of both the secondary volatile aerosol and the primary combustion aerosol, and trace gases $\mathrm{H}_{2} \mathrm{O}, \mathrm{NO}, \mathrm{NO}_{\mathrm{y}}, \mathrm{O}_{3}, \mathrm{CO}, \mathrm{CO}_{2}, \mathrm{SO}_{2}$, and meteorological parameters. The aerosol instrumentation consisted of six Condensation Particle Counters (CPC) set to different lower cutoff diameters (Schröder and Ström, 1997), Diffusion Screen Separators (Feldpausch et al., 2006), one Differential Mobility Analyser (DMA), one thermodenuder with two channels set to $20^{\circ} \mathrm{C}$ and $250^{\circ} \mathrm{C}$, two optical particle counters of types Passive Cavity Aerosol Spectrometer Probe (PCASP 100X) and Forward Scattering Spectrometer Probe (FSSP 300), and one Particle Soot Absorption Photometer (PSAP; Bond et al., 1999).
The combination of CPC and Diffusion Screen Separators with a DMA instrument and several optical particle spectrometers covered the entire size range from smallest particles in the nucleation mode $\left(D_{p}<0.01 \mu \mathrm{m}\right)$ to coarse mode particles in the far super-micron size range. The probed size range included optically active sub-micron particles $\left(0.05 \mu \mathrm{m}<D_{p}<1-2 \mu \mathrm{m}\right)$, coarse mode sea salt particles $\left(D_{p}>1 \mu \mathrm{m}\right)$ and particle sizes relevant for particle formation processes $\left(D_{p}<0.02 \mu \mathrm{m}\right)$. The non-volatile fraction in the sub-micron aerosol and the aerosol absorption coefficient were measured as well.

The aerosol population was subdivided into nucleation mode particles (NUC) with $D_{p}<0.014 \mu \mathrm{m}$, Aitken mode particles (AITK) with $0.014 \mu \mathrm{m}<D_{p}<0.1 \mu \mathrm{m}$, and accumulation mode particles (ACC) with $0.1 \mu \mathrm{m}<D_{p}<3.0 \mu \mathrm{m}$. Details of this separation of size ranges according to the applied instrumentation are given in Petzold et al. (2007), see also Table 1 for a comprehensive compilation. The aerosol absorption coefficient $\sigma_{a p}$ at a wavelength $\lambda=550 \mathrm{~nm}$, which was measured by the PSAP, can be converted to an "equivalent BC" mass concentration $\mathrm{BC}_{e}$ using a mass-specific absorption cross-section of $8 \mathrm{~m}^{2} \mathrm{~g}^{-1}$ (Bond and Bergstrom, 2006). The terminology "equivalent BC" follows a recommendation by Andreae and Gelencser (2006), since this BC value is derived from optical measurements and requires the assumption of a certain mass-specific absorption cross-section. Alternatively, this carbon fraction is also referred to as "light absorbing carbon" LAC (Bond and Bergstrom, 2006). Table 1 summarises the instrumentation of the aircraft.

If number or mass concentrations or aerosol absorption coefficients refer to standard temperature and pressure conditions STP $(273.14 \mathrm{~K}, 1013.25 \mathrm{hPa})$, they are given as particles per standard $\mathrm{cm}^{3}\left(\mathrm{scm}^{-3}\right)$, or $\mu \mathrm{g}$ per standard $\mathrm{m}^{3}$ $\left(\mu \mathrm{g} \mathrm{sm}^{-3}\right)$. These concentration data correspond to mixing ratios which do not depend on the respective pressure and temperature during the measurement. Otherwise concentration data refer to ambient conditions.

\subsection{The plume model}

One key to further understanding of the atmospheric transformation and processing of particles emitted from ships is the transformation of the exhaust plume during expansion and dilution. Von Glasow et al. (2003) proposed a Gaussian plume dispersion model which describes the evolution of the plume on a horizontal and a vertical scale. Dilution of the plume takes place by expansion and associated entrainment of marine background air. The model describes plume dispersion by two separate power laws for horizontal $\left(w_{p l}\right)$ and vertical $\left(h_{p l}\right)$ plume dimensions

$$
\begin{aligned}
& w_{p l}(t)=w_{0}\left(\frac{t}{t_{0}}\right)^{\alpha} \\
& h_{p l}(t)=h_{0}\left(\frac{t}{t_{0}}\right)^{\beta}
\end{aligned}
$$


Table 1. Instrumentation operated on board the research aircraft Falcon during ICARTT-ITOP 2004.

\begin{tabular}{|c|c|}
\hline Property & Instrumentation \\
\hline Aerosol properties & - \\
\hline $\begin{array}{l}\text { Number concentration; size distribution of } \\
\text { ultrafine particles }\end{array}$ & $\begin{array}{l}\text { Condensation Particle Counters }(\mathrm{CPC}) \text { operated at lower cut-off } \\
\text { diameters } D_{p, \min }=0.004,0.015 \text {, and approx. } 0.08 \mu \mathrm{m}(\mathrm{CPC} \& \text { Diffusion } \\
\text { Screen Separator DS })\end{array}$ \\
\hline \multicolumn{2}{|l|}{ Size distributions } \\
\hline Aitken mode & Differential Mobility Analyzer (DMA): $0.01<D_{p}<0.2 \mu \mathrm{m}$ \\
\hline Dry state, accumulation mode & Passive Cavity Aerosol Spectrometer Probe PCASP-100X: $0.1 \mu \mathrm{m}<D_{p}<3.0 \mu \mathrm{m}$ \\
\hline Ambient state, accumulation + coarse mode & Forward Scattering Spectrometer Probe FSSP 300: $0.3 \mu \mathrm{m}<D_{p}<20 \mu \mathrm{m}$ \\
\hline Volume fraction of volatile/refractory particles & $\begin{array}{l}\text { Thermodenuder }\left(T=20^{\circ} \mathrm{C} / 250^{\circ} \mathrm{C}\right) \text { connected to Condensation Particle Counters } \\
(\mathrm{CPC}) \text { operated at lower cut-off diameters } D_{\min }=0.004 \text {, } \\
0.015 \text {, and } 0.08 \mu \mathrm{m}(\mathrm{CPC} \& \text { Diffusion Screen Separator DS })\end{array}$ \\
\hline \multicolumn{2}{|l|}{ Aerosol optical properties } \\
\hline Trace gases & Particle Soot Absorption Photometer PSAP \\
\hline $\mathrm{NO} / \mathrm{NO}_{\mathrm{y}}$ & Chemiluminescence detector \\
\hline $\mathrm{CO}$ & VUV fluorescence \\
\hline $\mathrm{O}_{3}$ & Ion Trap Chemical Ionisation MS \\
\hline $\mathrm{CO}_{2}$ & IR absorption \\
\hline $\mathrm{H}_{2} \mathrm{O}$ & Tunable Diode Laser Spectrometer \\
\hline $\mathrm{SO}_{2}$ & Ion Trap Chemical Ionisation MS \\
\hline \multicolumn{2}{|l|}{ Atmospheric parameters } \\
\hline $\mathrm{T}, \mathrm{p}, \mathrm{RH}$ (BL, FT), 3D-wind velocity & Falcon standard instrumentation \\
\hline
\end{tabular}

with $w_{0}$ and $h_{0}$ referring to the initial width and height of the plume at age $t_{0}=1 \mathrm{~s}$. The respective initial values for $\mathrm{w}$ and $\mathrm{h}$ are $10 \mathrm{~m}$ and $5.5 \mathrm{~m}$ which were estimated from data in the literature (von Glasow et al., 2003). They approximately correspond to cross-sectional parameters, axes of a semi-ellipse, of a plume after $1 \mathrm{~s}$. Exponents $\alpha$ and $\beta$ are the plume expansion rates in the horizontal and vertical with "best guess" values of 0.75 and 0.60 (von Glasow et al., 2003). Using Eq. (1), plume dilution can be described by the evolution of a semi- elliptic plume cross section $A_{p l}=(\pi / 8) w_{p l} h_{p l}$ with time. Since the top of the MBL is considered impenetrable by the plume, the vertical expansion stops when the plume reaches the top of the MBL, i.e., $h_{p l}=z_{\mathrm{MBL}}$. The rate of change in concentration of a given compound in the plume $c_{p l}$ compared to its background value $c_{b g d}$ can be written as (von Glasow et al., 2003)

$$
\frac{d c_{p l}(t)}{d t}=\left\{\begin{array}{l}
\frac{\alpha+\beta}{t}\left(c_{b g d}-c_{p l}\right) h_{p l}(t)<z_{\mathrm{MBL}} \\
\frac{\alpha}{t}\left(c_{b g d}-c_{p l}\right) h_{p l}(t)=z_{\mathrm{MBL}}
\end{array}\right.
$$

The plume expansion rates $\alpha$ and $\beta$ can be derived from measurements of a chemically inert tracer like $\mathrm{CO}_{2}$ at different plume ages $t$ by applying Eq. (2). The quantity $\Delta \mathrm{CO}_{2}$, also referred to as excess $\mathrm{CO}_{2}$, describes the increase in $\mathrm{CO}_{2}$ above the average background mixing ratio by adding $\mathrm{CO}_{2}$ from the combustion process. $\Delta \mathrm{CO}_{2}$ is a direct measure of plume dilution, if the initial mixing ratio for exhaust conditions $\mathrm{CO}_{2 e x}$ is known.

The temporal evolution of any aerosol property or trace gas mixing ratio can be investigated by applying the plume dilution function. If the considered exhaust compound EX is conserved during plume expansion, then it follows the same dilution law like the chemically inert tracer $\mathrm{CO}_{2}$ and $\mathrm{EX}(t) / \Delta \mathrm{CO}_{2}(t)=$ constant. If the exhaust compound decays during plume expansion due to chemical degradation or particle coagulation, then $\mathrm{EX}(t) / \Delta \mathrm{CO}_{2}(t)$ decreases with increasing plume age, i.e.

$$
\frac{d}{d t} \frac{\operatorname{EX}(t)}{\Delta \mathrm{CO}_{2}(t)} \quad\left\{\begin{array}{cl}
=0, & \text { conservation of } \operatorname{EX}(t) \\
<0, & \text { loss of } \operatorname{EX}(t) \\
>0, & \text { production of } \operatorname{EX}(t)
\end{array}\right.
$$

Emission factors are calculated based on this behaviour. During plume encounters, observed peak concentrations of the exhaust constituent EX are transformed to STP conditions $\mathrm{EX}(\mathrm{STP})$. The peak volume mixing ratio $\triangle \mathrm{CO}_{2}$ is transformed to a mass concentration of $\mathrm{CO}_{2}$ at STP by multiplying by the molar weight of $\mathrm{CO}_{2}$ $\left(\mathrm{MW}_{\mathrm{CO}_{2}}=0.044 \mathrm{~kg} \mathrm{~mol}^{-1}\right)$ and dividing by the molar volume at STP $\left(\mathrm{V}_{\mathrm{MOL}}=0.0224 \mathrm{sm}^{3}\right)$. The mass ratio of $\mathrm{EX}(\mathrm{STP})$ per $\mathrm{CO}_{2}$ is converted to an emission factor by multiplication with the emission factor of $\mathrm{CO}_{2}\left(\mathrm{EI}_{\mathrm{CO}_{2}}\right)$ in units of $\mathrm{kg} \mathrm{CO}_{2}(\mathrm{~kg} \text { fuel })^{-1}$. The final equation for the calculation of an emission factor for species $\mathrm{EX}\left(\mathrm{EI}_{\mathrm{EXX}}\right)$ from the respective mass concentration and the $\Delta \mathrm{CO}_{2}$ volume mixing ratio is

$\mathrm{EI}_{\mathrm{EX}}=\frac{\mathrm{EX}(\mathrm{STP})}{\frac{\Delta \mathrm{CO}_{2}}{\mathrm{~V}_{\mathrm{MOL}}} \mathrm{MW}_{\mathrm{CO}_{2}}} \times \mathrm{EI}_{\mathrm{CO}_{2}}$ 
Table 2. Properties of aerosol emitted from a serial MAN B\&W four-stroke marine Diesel engine operating on heavy fuel oil with 2.21 wt- $\%$ sulphur and $0.03 \mathrm{wt}-\%$ ash; aerosol properties are given as raw exhaust average values at standard conditions $(273.14 \mathrm{~K}, 1013.25 \mathrm{hPa}) \mathrm{for}$ engine load conditions between $85 \%$ and $110 \%$. The average $\mathrm{CO}_{2}$ mixing ratio in the exhaust was $58000 \pm 5650 \mathrm{ppm}$.

\begin{tabular}{lcc}
\hline Particle property & Symbol, unit & Value \\
\hline Total particle number $\left(D_{p}>0.01 \mu \mathrm{m}\right)$ & $\mathrm{N}_{\mathrm{TOTAL}}, 10^{15} \mathrm{sm}^{-3}$ & $1.26 \pm 0.51$ \\
Non-volatile particle number $(D p>0.013 \mu \mathrm{m})$ & $\mathrm{N}_{N V}, 10^{14} \mathrm{sm}^{-3}$ & $4.63 \pm 1.0$ \\
Number fraction of non-volatile particles & $\mathrm{N}_{N V} / \mathrm{N}_{\mathrm{TOTAL}}, \%$ & $34 \pm 3$ \\
Total aerosol volume $\#$ & $\mathrm{~V}, 10^{-7} \mathrm{~m}^{3} \mathrm{sm}^{-3}$ & $1.52 \pm 0.45$ \\
Total particle mass (calculated from V and $\rho)$ & $\mathrm{PM}, \mathrm{mg} \mathrm{sm}^{-3}$ & $233 \pm 17$ \\
Total particle mass (chemical components) & $\mathrm{PM}, \mathrm{mg} \mathrm{sm}^{-3}$ & $243 \pm 16$ \\
Chemical composition in \% of PM mass & & $2.7 ; 21.4 ; 4.2 ; 39.8 ; 31.9$ \\
EC; OM; ash; sulphate; water & & \\
PM fraction of non-volatile compounds & $\mathrm{PM}_{N V} / \mathrm{PM}, \%$ & $29 \pm 2$ \\
(EC+OM+ash)/PM & $\rho, \mathrm{kg} \mathrm{m}^{-3}$ & $1230 \pm 2$ \\
Particle density (chemical composition) & $\mathrm{EI}_{\mathrm{TOTAL}},\left(\mathrm{kg} \mathrm{fuel}^{-1}\right.$ & $34.3 \pm 12.6 \times 10^{15}$ \\
Number emission factors for total particles & $\mathrm{EI}_{\mathrm{TOTAL}}, \mathrm{kWh}^{-1}$ & $7.27 \pm 2.71 \times 10^{15}$ \\
& $\mathrm{EI}_{N V},\left(\mathrm{~kg} \mathrm{fuel}^{-1}\right.$ & $12.6 \pm 2.3 \times 10^{15}$ \\
Number emission factors for non-volatile particles & $\mathrm{EI}_{N V}, \mathrm{kWh}^{-1}$ & $2.68 \pm 0.51 \times 10^{15}$ \\
& $\mathrm{EI}_{\mathrm{EC}},{\mathrm{mg}\left(\mathrm{kg} \mathrm{fuel}^{-1}\right.}^{-1}$ & $179 \pm 18$ \\
Mass emission factors for elemental carbon & $\mathrm{EI}_{\mathrm{EC}}, \mathrm{mg} \mathrm{kWh}^{-1}$ & $38 \pm 4$ \\
\end{tabular}

\# calculated from size distributions assuming spherical particle shape.

Equation (3) yields the emission factor in units of mass of compound EX per $\mathrm{kg}$ fuel or number of particles per $\mathrm{kg}$ fuel. It is evident that emission factors can be determined by Eq. (3) only for those compounds which are conserved during plume expansion. As soon as $\operatorname{EX}(t) / \Delta \mathrm{CO}_{2}(t)$ varies with plume age $t$, the emission factor becomes a function of plume age and effective emission indices have to be considered instead. If the corresponding measurements of EX and $\Delta \mathrm{CO}_{2}$ have about the same time response, the ratio of the observed peak concentrations in the plume can be used for the calculation of emission factors, otherwise integrals have to be used (Schlager et al., 2007).

In the following, the plume dilution function and the observed behaviour of aerosol properties with plume age and for emission conditions are used to discuss particle transformation processes and plume lifetimes. The test rig studies provide the boundary conditions for aerosol properties at emission conditions. The ship corridor survey flight provides aerosol and plume properties for aged plumes which have mixed with the MBL. The core of the data analysis forms the single plume study which bridges the gap between emission and well-aged plumes. The presentation of results follows this overall structure.
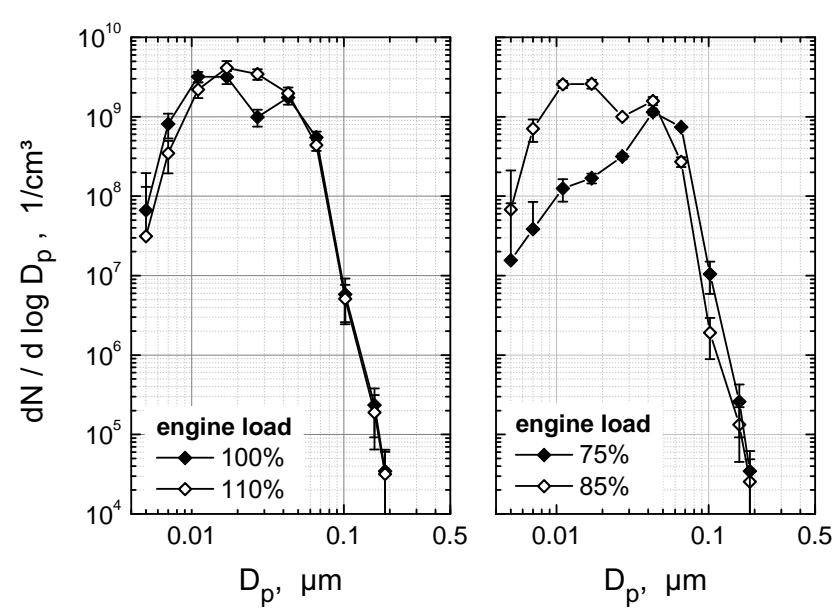

Fig. 3. HERCULES test bed measurements of aerosol size distributions by a Differential Mobility Analyser. Size distributions refer to the indicated load conditions of a serial MAN engine operating on heavy fuel oil.

\section{Results}

\subsection{Test rig studies}

Table 2 summarises the average physical and chemical properties of an aerosol emitted from the indicated four-stroke serial engine running on $85-110 \%$ load. Number concentrations in the raw exhaust gas are $1.26 \pm 0.51 \times 10^{15} \mathrm{sm}^{-3}$. 
Applying a thermodenuder removes $2 / 3$ of the particles, leaving behind $4.63 \pm 1.0 \times 10^{14}$ non-volatile particles per $\mathrm{sm}^{-3}$. The total aerosol is characterised by a strong mode centred at $D_{p}=0.015 \mu \mathrm{m}$ and a second but slightly weaker mode centred around $D_{p}=0.05 \mu \mathrm{m}$. No particles are observed with diameters $>0.25 \mu \mathrm{m}$. Typical size distributions are shown in Fig. 3 for the investigated load conditions. The observed bi-modal structure of the size distribution is present for load conditions $>75 \%$. For an engine load of $110 \%$ the size distribution is still bi-modal although the gap between the nucleation mode particles composed of sulphuric acid - water droplets and the combustion mode particles has almost vanished. We explain the observation by an increasing production of sulphuric acid with increasing engine load or combustion temperature, respectively. This increased availability of sulphuric acid leads to an increase in particle production and in turn to an increase in particle size of the nucleation mode particles caused by particle coagulation and gas phase deposition on already existing nucleation mode particles. The mode of small particles starts to vanish at load conditions $<75 \%$, i.e., the combustion particle mode centred at $D_{p}=0.05 \mu \mathrm{m}$ depends only weakly on the engine load, while the mode of smaller particles is heavily influenced.

The average fractional chemical composition in $\%$ of total mass at $85-110 \%$ load is $2.7 \%$ EC, $21.4 \%$ OM, $4.2 \%$ ash, $39.8 \%$ sulphate, and $31.9 \%$ sulphate-bound water. In the course of similar test experiments, but with a different engine and different fuel in 2003, we found an increase of the sulphate mass fraction from $41 \%$ at $50 \%$ load to $47 \%$ at $100 \%$ load, while the EC mass fraction decreased (Petzold et al., 2004). Thus, the evolution of a small particle mode in the size range $D_{p}<0.03 \mu \mathrm{m}$ is associated with an increase of sulphate, indicating that the small particles are composed predominantly of sulphuric acid water clusters while the larger combustion particle mode contains most of the non-volatile matter as EC, OM and ash. A similar behaviour was found during the 2006 test, which will be reported elsewhere with more detail.

Comparisons with existing data yield an agreement of the main combustion particle mode found at $D_{p}=0.04$ $0.06 \mu \mathrm{m}$ for four-stroke engines (Lyyränen et al., 1999) and at $D_{p}=0.04-0.05 \mu \mathrm{m}$ for two-stroke engines (Kasper et al., 2007). More detailed comparisons with respect to the volatile particle mode at $D_{p} \leq 0.02 \mu \mathrm{m}$ are difficult since neither details on the modal structure of the exhaust aerosol nor absolute number concentrations, nor chemical composition data are given for four-stroke engines. For two-stroke engines, however, a bi-modal structure is observed as well (Kasper et al., 2007). Total particle numbers of $1-8 \times 10^{15} \mathrm{kWh}^{-1}$ at $100 \%$ load are of the same order as our observations.

Although the engines studied in the test rig experiments (four-stroke) and during the ship plume measurements (twostroke) are different, the data summarised in Table 2 are used as reference for fresh exhaust conditions. This approach is justified since for the main combustion mode, no significant
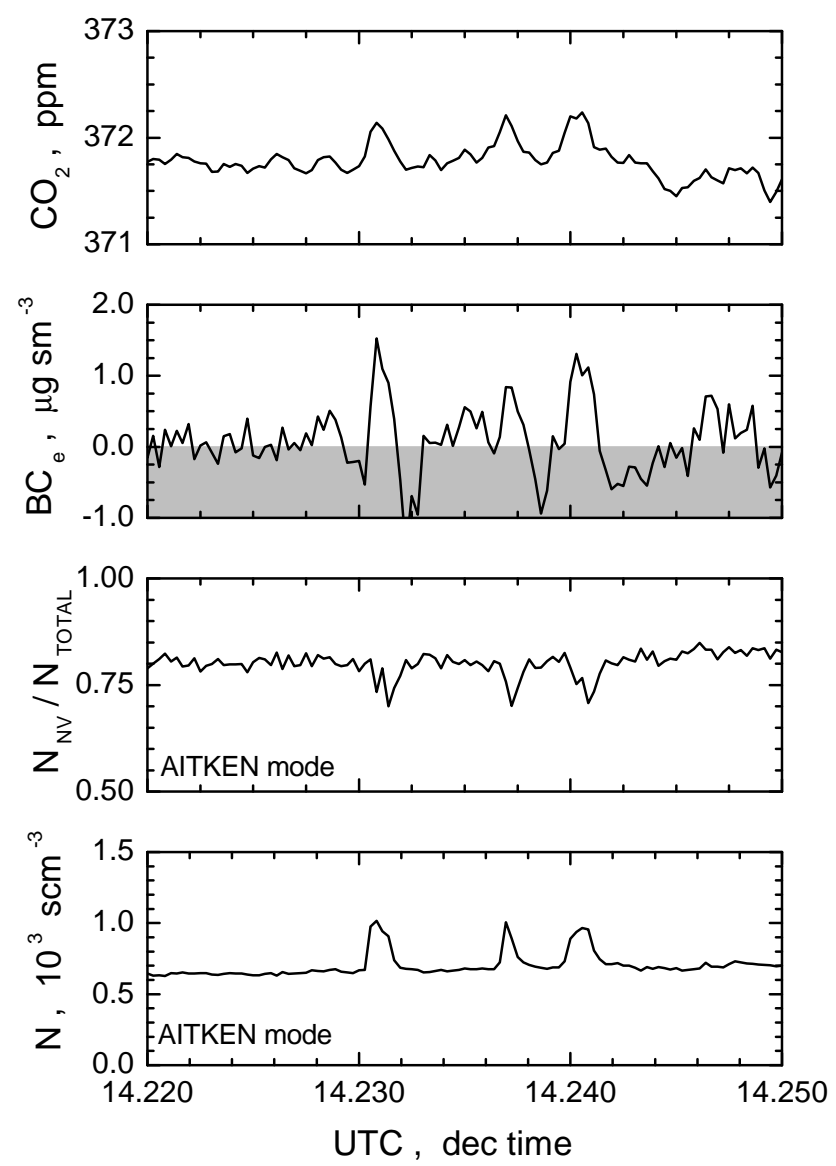

Fig. 4. Aerosol properties in aged ship plumes: $\mathrm{CO}_{2}$, equivalent $\mathrm{BC}_{e}$ mass concentration (grey shaded area indicates unphysical negative $\mathrm{BC}_{e}$ values $<$ limit of detection), non-volatile fraction of the Aitken mode aerosol, and number concentration of the Aitken mode during three distinct plume encounters.

differences were found between two-stroke and four-stroke marine diesel engines.

\subsection{The corridor flight}

Now we move from marine diesel engine studies to studies of ship plumes embedded in the MBL. The ship plumes encountered by our aircraft are easily identified as peaks in the time series of both particle number concentration and $\mathrm{CO}_{2}$ in Fig. 4. In MBL air outside of plumes, average particle number concentrations are $690 \pm 30 \mathrm{~cm}^{-3}$ for AITK mode particles and $150 \pm 10 \mathrm{~cm}^{-3}$ for ACC mode particles. The non-volatile fraction of the total aerosol is $82 \pm 3 \%$ for AITK mode particles and $100 \%$ for ACC mode particles. No particle nucleation is observed. In Fig. 4, three well separated plumes can be identified in the $\mathrm{CO}_{2}$ signal. Excess $\mathrm{CO}_{2}$ can be determined with good accuracy by subtracting the average background value around the peak from the peak value itself. 
Table 3. Data of the investigated MAERSK container vessel.

\begin{tabular}{ll}
\hline Size & 90560 RT (registered tonnage) \\
\hline Type & Container \\
Capacity & 6418 TEU (twenty feet equivalent unit) \\
Engine & MAN B\&W two-stroke marine diesel engine \\
Fuel type & Heavy fuel oil \\
Sulphur content & 2.45 wt- $\%$ \\
Ash content & 0.03 wt- $\%$ \\
\hline
\end{tabular}

A conservative estimate of the average uncertainty of $\mathrm{CO}_{2}$ is 0.4 ppm (Schlager et al., 2007).

The plumes plotted in Fig. 4 are characterised by peak $\Delta \mathrm{CO}_{2}=0.45-0.55 \mathrm{ppm}$. Coincident with an increase in $\mathrm{CO}_{2}$, increases in both AITK mode particle number concentration and equivalent $\mathrm{BC}$ mass concentration are observed. The AITK mode number concentration is almost doubled from the background value to $1000-1500 \mathrm{~cm}^{-3}$. Simultaneously, the non-volatile fraction of AITK mode particles decreases from the background value of $82 \%$ to $72 \pm 5 \%$ inside the aged plumes due to externally mixed volatile particles in the exhaust plumes. All signals are synchronous in time.

For aged plume conditions, the observations from the corridor flight are taken as average values describing well-aged ship plumes. More detailed analyses including plume ageing processes are not possible since $\Delta \mathrm{CO}_{2}$ is associated with a large relative error of more than $50 \%$ which does not permit a determination of plume age from the increase in $\mathrm{CO}_{2}$ relative to the marine background air. Furthermore, the quantitative analysis of $\mathrm{BC}_{e}$ peaks is not possible since peaks are almost always associated with unphysical negative values in $\mathrm{BC}_{e}$ because the instrument is operating below the detection limit outside of ship plumes. As is discussed in the next section, the situation is different for strong plume encounters when the PSAP signal is well above its detection limit. However, the engine exhaust studies from HERCULES and the aged plume data from the corridor flight frame the analysis and interpretation of the data from the single plume study described in the following section.

\subsection{The single plume study}

During the Single Plume Study on 30 July 2004, the plume of a large container vessel operated by MAERSK shipping company was investigated. Vessel data and key properties of the burnt fuel are compiled in Table 3. The vessel was operating on heavy fuel oil (HFO) with a sulphur content of $2.45 \%$-mass, which is close to the sulphur fuel content of the emission testing. The plume study was arranged in close collaboration with the owner and the captain of the vessel. The flight track of the aircraft in the exhaust plume of the vessel was designed such that the 3-D structure of the evolving

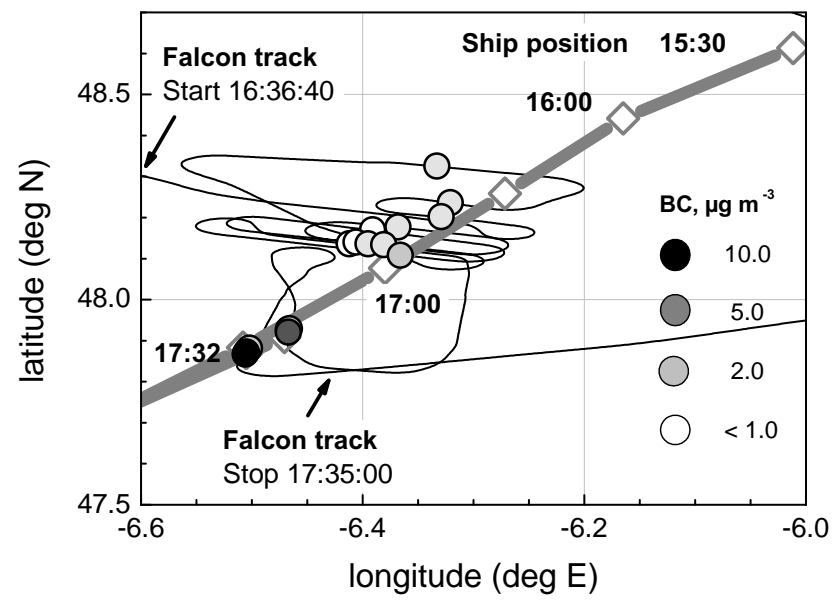

Fig. 5. Tracks of the source ship and the research aircraft Falcon during the Single Plume Study; symbol colours represent equivalent Black Carbon mass concentrations in the plume.

plume was covered from close to the source downwind to as far as the plume position was identifiable by the pilots of the aircraft. In Fig. 5 the flight track is shown together with plume encounters. Symbol colours represent the black carbon mass concentration in the plume. During the entire study the crew reported engine operation data and meteorological data of the MBL as recorded by the on-board instruments. Table 4 summarises data on the position of the vessel, MBL meteorological data, cruising speed, engine load, and fuel flow.

The weather conditions during the single plume study were characterised by a high pressure system between Ireland and Great Britain with a surface pressure of about $1020 \mathrm{hPa}$, surface temperatures of $292 \mathrm{~K}$ and moderate horizontal wind speeds increasing from $2 \mathrm{~m} \mathrm{~s}^{-1}$ at the beginning of the study to $11 \mathrm{~ms}^{-1}$ at study end. The wind direction changed from north-eastern winds near the surface up to approx. $200 \mathrm{~m}$ a.s.l. to southerly winds at higher altitudes. During the single plume study, the MBL was well mixed as is indicated by the vanishing vertical gradient of the potential temperature $\theta$ and of the particle number density inside the MBL, see Fig. 6 for details. Combining vertical profiles of particle number concentrations, potential temperature, relative humidity, and horizontal wind speed, all quantities show a strong change with altitude around 550 to $650 \mathrm{~m}$ a.s.l. which is therefore assumed to represent the top of the MBL.

Engine operation data and fuel properties were used by the manufacturer of the engine for calculating the average emissions of the vessel, which are compiled in Table 5. The $\mathrm{CO}_{2}$

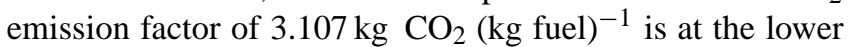
bound of values of $3.135-3.176 \mathrm{~kg} \mathrm{CO}_{2}(\mathrm{~kg} \text { fuel })^{-1}$ reported in the literature (e.g., Sinha et al., 2003). This $\mathrm{CO}_{2}$ emission factor is required for the calculation of emission factors 
Table 4. Operation conditions of the MAERSK vessel, and MBL properties during the ship plume study on 30 July 2004.

\begin{tabular}{|c|c|c|c|c|c|c|c|c|c|c|c|c|c|}
\hline \multirow[t]{2}{*}{ UTC } & \multicolumn{2}{|c|}{ Position } & \multicolumn{2}{|c|}{ Cruise } & \multicolumn{2}{|c|}{ Wind } & \multicolumn{2}{|c|}{ MBL } & \multicolumn{3}{|c|}{ Main Engine } & \multicolumn{2}{|c|}{ Aux. Engine } \\
\hline & Latitude & Longitude & $\begin{array}{c}\text { Dir cruise } \\
\text { deg }\end{array}$ & $\begin{array}{c}\mathrm{v}_{\text {cruise }} \\
\mathrm{kn}\left(\mathrm{m} \mathrm{s}^{-1}\right)\end{array}$ & $\begin{array}{c}\text { Dir }_{\text {wind }} \\
\text { deg }\end{array}$ & $\begin{array}{l}\mathrm{v}_{\text {wind }} \\
\mathrm{m} \mathrm{s}^{-1}\end{array}$ & $\mathrm{p} \mathrm{hPa}$ & $\mathrm{T}^{\circ} \mathrm{C}$ & Power kW & $\begin{array}{l}\text { Power } \\
\% \max \end{array}$ & $\begin{array}{c}\text { Fuel flow } \\
\mathrm{kg} \mathrm{h}^{1}\end{array}$ & Power kW & $\begin{array}{c}\text { Fuel flow } \\
\mathrm{kg} \mathrm{h}^{1}\end{array}$ \\
\hline $15: 30$ & $48^{\circ} 36.8 \mathrm{~N}$ & $06^{\circ} 00.7 \mathrm{~W}$ & 217 & $23.7(12.18)$ & 0 & 2 & 1021.6 & 19.9 & 46960 & 85 & 9016 & 2440 & 618.17 \\
\hline $16: 00$ & $48^{\circ} 26.5 \mathrm{~N}$ & $06^{\circ} 09.9 \mathrm{~W}$ & 205 & $23.7(12.18)$ & 350 & 3 & 1021.0 & 19.9 & 46960 & 85 & 9016 & 2360 & 597.20 \\
\hline $16: 30$ & $48^{\circ} 15.5 \mathrm{~N}$ & $06^{\circ} 16.3 \mathrm{~W}$ & 201 & $23.4(12.03)$ & 335 & 5 & 1020.5 & 18.6 & 46960 & 85 & 9016 & 2330 & 590.31 \\
\hline $17: 00$ & $48^{\circ} 04.6 \mathrm{~N}$ & $06^{\circ} 22.8 \mathrm{~W}$ & 201 & $23.5(12.08)$ & 350 & 8 & 1020.6 & 18.9 & 46960 & 85 & 9016 & 2430 & 615.64 \\
\hline $17: 30$ & $47^{\circ} 53.0 \mathrm{~N}$ & $06^{\circ} 30.5 \mathrm{~W}$ & 208 & $23.8(12.47)$ & 340 & 11 & 1020.4 & 19.0 & 46960 & 85 & 9016 & 2380 & 602.97 \\
\hline
\end{tabular}
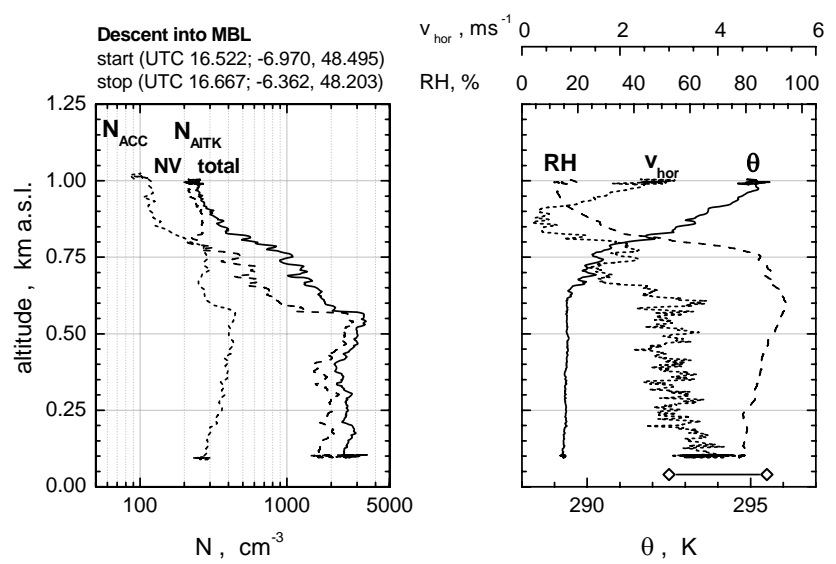

Fig. 6. Vertical structure of the marine boundary layer during the Single Plume Study.

Table 5. Composition of the MAERSK vessel gaseous emissions as calculated from fuel type and main engine operation conditions: engine power $46960 \mathrm{~kW}$, engine fuel flow $9016 \mathrm{~kg} \mathrm{~h}^{-1}$, mass flow of exhaust $457000 \mathrm{~kg} \mathrm{~h}^{-1}$.

\begin{tabular}{lcc}
\hline Gaseous species & vol $-\%$ & EI, $\mathrm{kg}(\mathrm{kg} \text { fuel })^{-1}$ \\
\hline $\mathrm{CO}_{2}$ & 4.036 & 3.107 \\
$\mathrm{H}_{2} \mathrm{O}$ & 4.243 & 1.41 \\
$\mathrm{SO}_{2}$ & 0.043 & 0.051 \\
$\mathrm{NO}_{\mathrm{x}}$ & 0.140 & 0.112 \\
Plume Observations & & \\
$\mathrm{CO}_{2}^{*}$ & & $3.135-3.20$ \\
$\mathrm{NO}_{\mathrm{X}}^{\#}$ & & $0.096-0.109$ \\
$\mathrm{SO}_{2}^{\#}$ & & $0.040-0.046$ \\
\hline
\end{tabular}

* Hobbs et al. (2000), Sinha et al. (2003).

\# Schlager et al. (2007).

from concentration measurements according to Eq. (3). The emission factors for $\mathrm{NO}_{\mathrm{x}}$ and $\mathrm{SO}_{2}$ and observed differences between calculated and measured values are discussed in detail by Schlager et al. (2007).

Plume encounters observed during the Single Plume Study are shown in Fig. 7 as time series of various properties. The strength of the plume event was rated according to $\Delta \mathrm{CO}_{2}$.
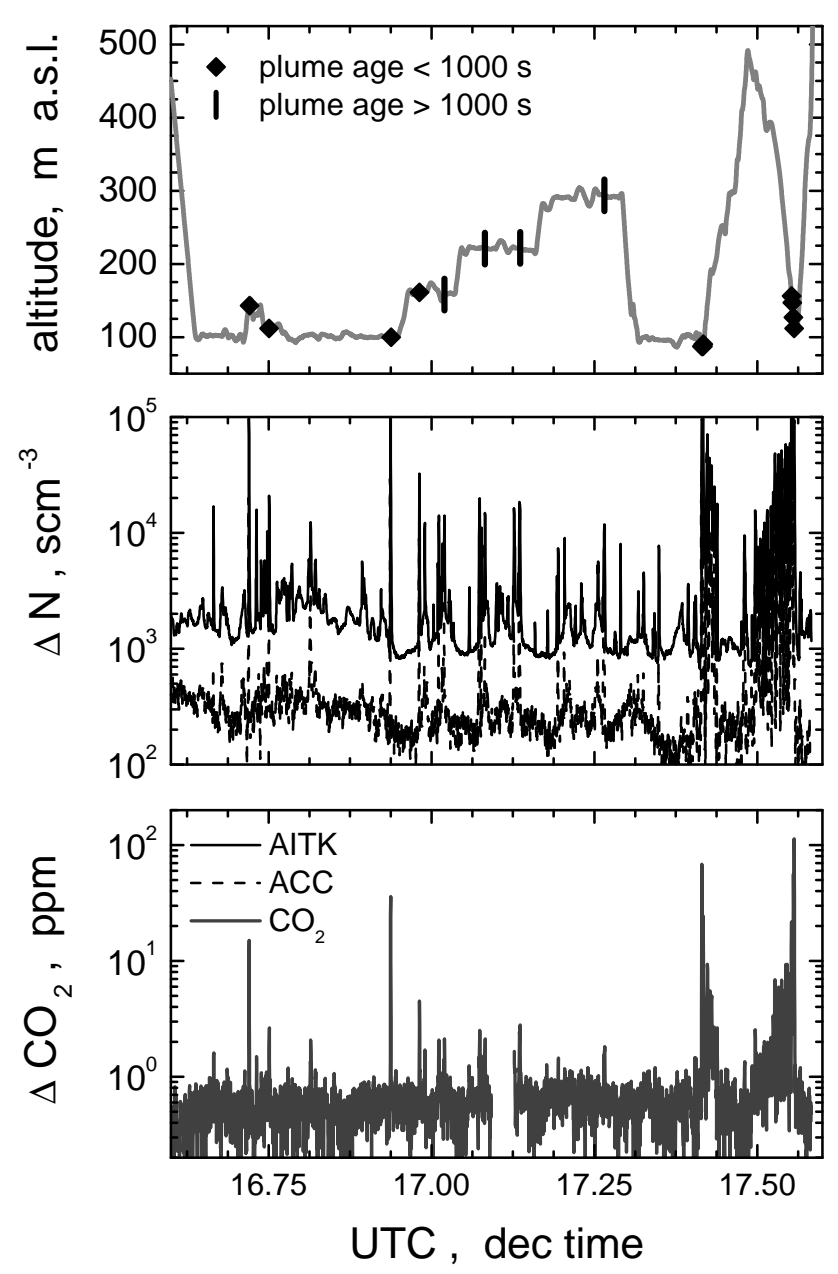

Fig. 7. Time series of flight altitude in $\mathrm{m}$ above sea level (a.s.1.): excess number concentration $\Delta \mathrm{N}$ for Aitken (AITK, solid line) and accumulation (ACC, dashed line) mode particles, and excess $\mathrm{CO}_{2}$ $\left(\Delta \mathrm{CO}_{2}\right.$, thick gray line) during the Single Plume Study. 


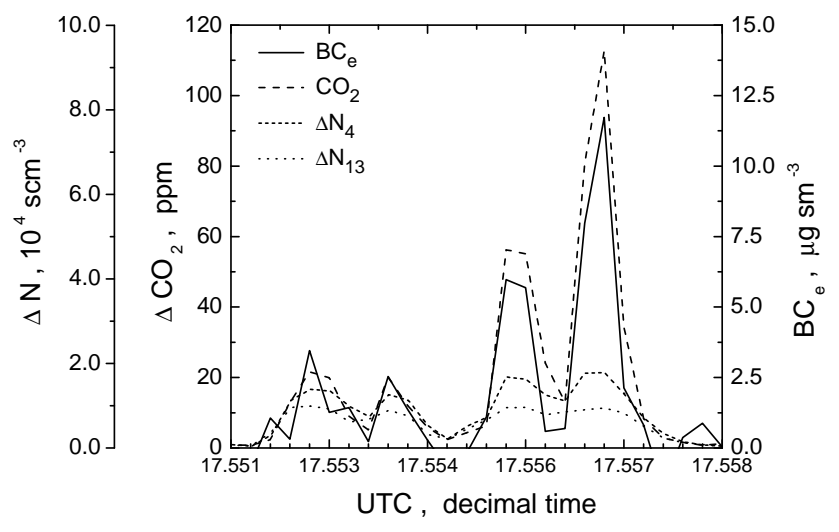

Fig. 8. Raw data of the closest plume encounter: equivalent black carbon from aerosol light absorption measurement $\left(\mathrm{BC}_{e}\right.$; solid line), excess $\mathrm{CO}_{2}\left(\Delta \mathrm{CO}_{2}\right.$ : dashed line), and excess number concentrations of particles with $D>4 \mathrm{~nm}\left(\Delta \mathrm{N}_{4}\right.$ : short dotted line $)$ and $D>13 \mathrm{~nm}\left(\Delta \mathrm{N}_{13}\right.$ : doted line). Maximum detectable number concentrations were limited to $2 \times 10^{4} \mathrm{scm}^{-3}$ by instrument limitations.

In the far field of the plume $\Delta \mathrm{CO}_{2}<10 \mathrm{ppm}$, while close to the source, $\Delta \mathrm{CO}_{2}$ even exceeded $100 \mathrm{ppm}$. Figure 8 shows that near the source, the $\mathrm{BC}$ mass concentration increased to $10 \mu \mathrm{g} \mathrm{sm}^{-3}$. However, the Condensation Particle Counters (CPC) did not respond to the increasing number of exhaust particles. Thus, while $\Delta \mathrm{CO}_{2}$ and $\mathrm{BC}_{e}$ simultaneously increase by a factor of three during approach to the source, particle number concentrations remain at a value of about $2 \times 10^{4} \mathrm{scm}^{-3}$ which corresponds to the upper detection limit of this type of condensation particle counter due to particle coincidence in the instrument. Particle number density data were therefore accessible only for plume ages beyond $10^{3} \mathrm{~s}$ when the plume was sufficiently diluted.

\subsubsection{Plume dispersion}

Plume peak data on the basis of 95-percentile values with respect to the analysed plume sequence were used to calculate plume dilution and emission factors of the respective particulate matter properties. In the case of near field plume encounters $\left(t<10^{3} \mathrm{~s}\right)$, accessible data were $\Delta \mathrm{CO}_{2}$ and $\Delta \mathrm{BC} e$, while in the case of far field plume encounters $\left(t>10^{3} \mathrm{~s}\right)$, accessible data were $\Delta \mathrm{CO}_{2}$ and $\Delta \mathrm{N}$. According to von Glasow et al. (2003) and to Eq. (2), the decay of a chemically inert species like $\Delta \mathrm{CO}_{2}$ in a dissolving plume is described by two exponents $\alpha$ and $\beta$ which refer to the horizontal and vertical spreading of the plume, respectively, with the plume age $t$ being the independent variable.

The plume age was determined by backward trajectory analyses from the time shift between emission by the vessel and probing of the plume by the Falcon. Input data were the positions of the vessel and of the aircraft as a function of time, and the horizontal wind field as measured by the Falcon meteorological instrumentation. Using this method, the plume age can be determined within an uncertainty of 10$20 \%$ (Schlager et al., 2007). Following this analysis, plumes were probed at ages between $60 \mathrm{~s}$ and $1650 \mathrm{~s}$.

Using ECMWF wind field data of lower spatial and temporal resolution instead of directly measured wind field data yields larger plume ages. The time difference between emission and plume detection which is taken as the plume age, depends crucially on the horizontal wind speed which is the driving force of the transport from the exhaust duct to the point of measurement. The shift to larger plume ages when using ECMWF data is mainly caused by the lower horizontal wind speeds of the modal compared to the real measurements. However, both plume ages are highly correlated with $r^{2}=0.961$ for 10 analysed plume encounters and a regression line of $t_{\mathrm{ECMWF}}=1.272( \pm 0.0426) t_{\text {measured }}$. In the course of this study, the plume ages from the directly measured wind fields were used.

According to Eqs. (1) and (2), a plot of $\Delta \mathrm{CO}_{2}$ as a function of plume age $t$ should provide two different regimes: the young plume age where expansion occurs in both horizontal and vertical direction since the plume height is less than the MBL height, and the more aged plume, where expansion occurs only in the horizontal direction, since the plume height already reached the top of the MBL. These two regimes are indeed observed as can be taken from Fig. 9. Fitting of the respective lines delivers $\alpha=0.74-0.76$ and $\beta=0.70-0.80$ from the slopes of the near field sequences (solid line: $\mathrm{m}=\alpha+\beta$ ), and of the far filed sequences (dashed line: $\mathrm{m}=\alpha$ ). Respective best guess values by von Glasow et al. (2003) for a set of analysed plumes are $\alpha=0.75$ and $\beta=0.60$.

The obtained parameter $\alpha$ for the horizontal dispersion agrees remarkably well with the literature data, while the parameter $\beta$ for the vertical dispersion strongly depends on the stability of the MBL. The transition from plume expansion in both the horizontal and the vertical direction to expansion in the horizontal direction only is observed at a plume age of approximately $1000 \mathrm{~s}$. After this age, the plume should extend over the entire MBL. The earliest that ship tracks can form is at this stage, when the emitted particles have reached the top of the MBL. In the current single plume study, the MBL was well mixed, resulting in a larger $\beta$ value than given in the literature. Nevertheless, the observations justify the application of a Gaussian-type model for the parameterisation of ship plume dispersion for our specific case, see also Fig. 9. In a turbulent MBL, the situation might be different.

\subsubsection{Emission factors}

As described in Sect. 2.3, the determination of an emission factor for a given species requires a constant ratio of exhaust species concentration $\mathrm{EX}(t)$ to $\Delta \mathrm{CO}_{2}(t)$ during plume expansion. Then Eq. (3) can be applied. Figure 10 shows the results of linear regression analyses for equivalent black carbon $\triangle \mathrm{BC}_{e}$ as a function of $\Delta \mathrm{CO}_{2}$ for near field conditions with $\triangle \mathrm{BC}_{e}$ well above the detection limit of the instrument, 


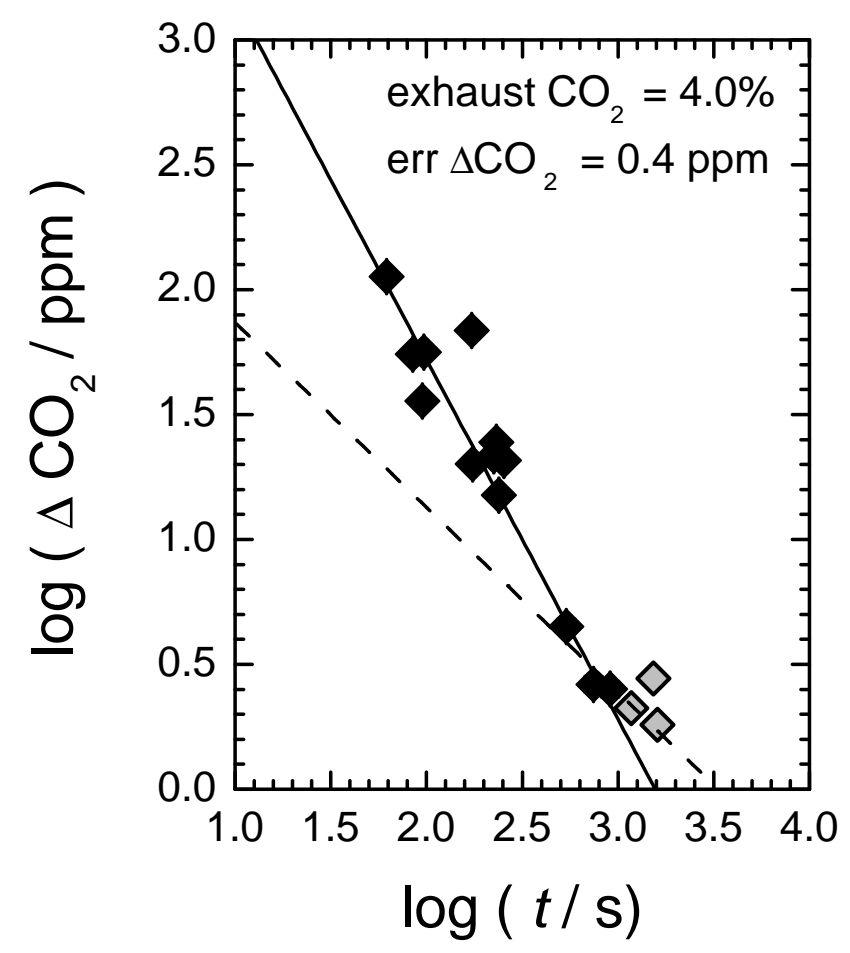

Fig. 9. Excess $\mathrm{CO}_{2}$ as a function of plume age: experimental observation (symbols) and results (solid and dashed lines) from an adapted Gaussian plume model according to von Glasow et al. (2003). The solid line represents $\mathrm{m}=\alpha+\beta$, the dashed line is $\mathrm{m}=\alpha$; black symbols refer to near field data with plume ages $>1000 \mathrm{~s}$, gray symbols to far field data with plume ages $>1000 \mathrm{~s}$.
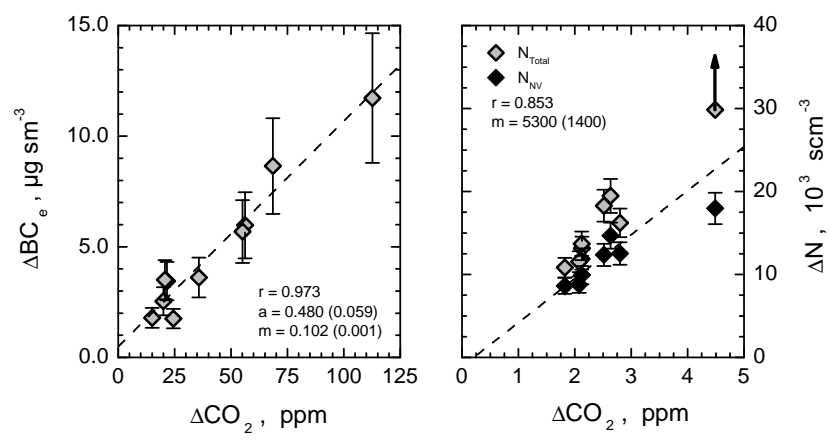

Fig. 10. Emission factors derived from the MAERSK vessel plume: $\mathrm{BC}_{e}$ from near field data with $\mathrm{BC}_{e}$ above the resolution of the instrument; $\mathrm{N}_{\mathrm{NV}}$ from far field data with $\mathrm{N}_{\mathrm{NV}}$ below the CPC coincidence level of $20000 \mathrm{scm}^{-3}$. Intersect a, slope $\mathrm{m}$, and correlation coefficient $r$ of the regression lines are added to the panels (uncertainties in parentheses). The arrow at the largest $\mathrm{N}_{\text {total }}$ value indicates the underestimation of this value because of instrument overflow.

and for non-volatile particles $\Delta \mathrm{N}_{N V}$ as a function of $\Delta \mathrm{CO}_{2}$ from far field data with $\Delta \mathrm{N}_{N V}$ below the coincidence level of the CPC. For both aerosol properties, a statistically signif-

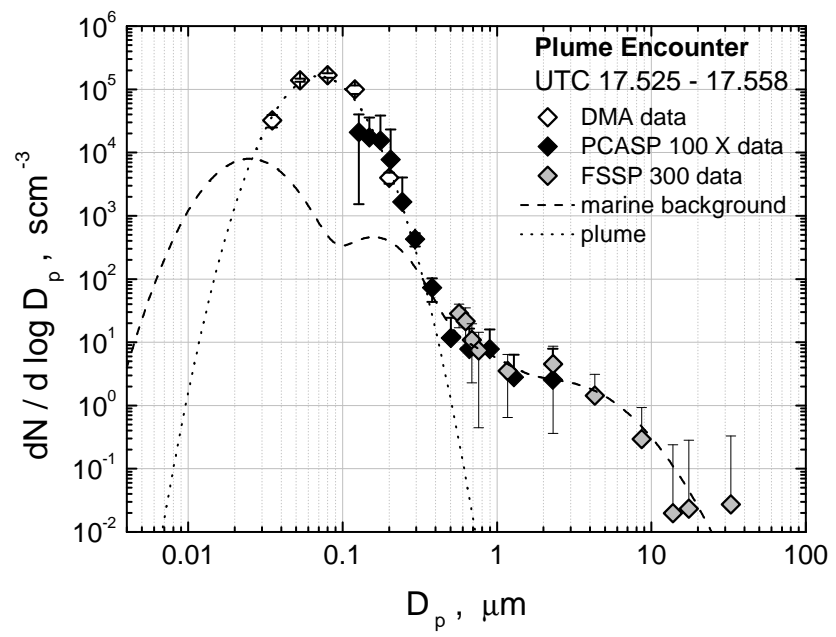

Fig. 11. Composite size distributions from data from DMA. PCASP 100X and FSSP 300 for a strong plume encounter and for a marine background case; the log-normal size distribution represents the exhaust particle mode.

icant linear relationship is found indicating a ratio to $\Delta \mathrm{CO}_{2}$ independent of plume age. Tables 6 and 7 summarise the analysis of this functional dependence for all plume encounters.

Averaging over all plume encounters yields emission factors of $174.2 \pm 42.5 \mathrm{mg} \mathrm{BC}$ ( kgfuel $)^{-1}$ for equivalent $\mathrm{BC}$, $13.6 \pm 2.4 \times 10^{15}(\mathrm{~kg} \text { fuel })^{-1}$ by number for total particles and $8.8 \pm 1.0 \times 10^{15}(\mathrm{~kg} \text { fuel })^{-1}$ by number for non-volatile particles. The respective emission factor for accumulation mode particles is $2.3 \pm 0.7 \times 10^{15}(\mathrm{~kg} \text { fuel })^{-1}$. Thus, about $65 \%$ by number of emitted particles contain a non-volatile core, while less than $20 \%$ by number are larger than $0.1 \mu \mathrm{m}$ in diameter. For the total aerosol which also includes volatile nucleation and Aitken mode particles, the emission factor is more variable since for higher $\Delta \mathrm{CO}_{2}$ values there is no longer a linear dependency obtained. Note the high number concentration $\Delta \mathrm{N}_{D>13 \mathrm{~nm}}$ for high $\Delta \mathrm{CO}_{2}$ values, as indicated by the arrow in the top right corner of right panel of Fig. 10 which refers to CPC counter overflow in the young plume.

The obtained emission factors for the total aerosol are at the lower end of the range of reported values of 1.2$6.2 \times 10^{16}(\mathrm{~kg} \text { fuel })^{-1}$. The accumulation mode particle emission factor fits well into the reported range of $1-5 \times 10^{15}(\mathrm{~kg}$ fuel $)^{-1}$ (Sinha et al., 2003). The $\mathrm{BC}_{e}$ emission factor is in very close agreement with the reported value of $180 \pm 20 \mathrm{mg}$ BC $(\mathrm{kg} \text { fuel })^{-1}$ (Sinha et al., 2003). For non-volatile particles, no observational data are available for comparison. In summary, the determined emission factors for equivalent black carbon mass and for particle number of several aerosol fractions either fall within the range of reported values or add new information to the topic. 
Table 6. Particle number emission factors EI, referring to $\mathrm{N}_{\text {TOTAL }}$ : total aerosol measured by a Condensation Particle Counter with lower cutoff diameter of $10 \mathrm{~nm}$, and to $\mathrm{N}_{N V}$ : non-volatile aerosol measured by a Condensation Particle Counter connected to a Thermodneuder $\left(T=250^{\circ} \mathrm{C}\right)$.

\begin{tabular}{|c|c|c|c|c|c|c|c|c|c|c|}
\hline UTC & $\Delta \mathrm{CO}_{2}$ & $\Delta \mathrm{N}_{\text {TOTAL }}$ & $\Delta \mathrm{N}_{\mathrm{NV}}$ & $\Delta \mathrm{N}_{\mathrm{ACC}}$ & $\mathrm{EI}_{\mathrm{TOTAL}}$ & $\mathrm{EI}_{\mathrm{NV}}$ & $\mathrm{EI}_{\mathrm{ACC}}$ & $\mathrm{EI}_{\mathrm{TOTAL}}$ & $\mathrm{EI}_{\mathrm{NV}}$ & $\mathrm{EI}_{\mathrm{ACC}}$ \\
\hline dec. time & ppm & $10^{10} \mathrm{sm}^{-3}$ & $10^{10} \mathrm{sm}^{-3}$ & $10^{10} \mathrm{sm}^{-3}$ & \multicolumn{3}{|c|}{$10^{15}\left(\mathrm{~kg} \mathrm{CO}_{2}\right)^{-1}$} & \multicolumn{3}{|c|}{$10^{15}(\mathrm{~kg} \text { fuel })^{-1}$} \\
\hline 16.98167 & 4.488 & n.a. & 1.80 & 0.84 & n.a. & 2.36 & 0.95 & n.a. & 7.342 & 2.95 \\
\hline 16.75083 & 2.63 & 2.13 & 1.47 & 0.56 & 4.77 & 3.29 & 1.08 & 14.82 & 10.23 & 3.36 \\
\hline 17.07389 & 2.51 & 2.38 & 1.24 & 0.36 & 5.58 & 2.90 & 0.73 & 17.33 & 9.02 & 2.27 \\
\hline 17.02 & 2.13 & 1.45 & 0.99 & 0.23 & 4.03 & 2.76 & 0.55 & 12.51 & 8.57 & 1.72 \\
\hline 17.13611 & 2.80 & 1.80 & 1.25 & 0.46 & 3.80 & 2.64 & 0.83 & 11.82 & 8.20 & 2.57 \\
\hline 17.08222 & 2.12 & 1.82 & 1.19 & 0.13 & 5.06 & 3.30 & 0.31 & 15.73 & 10.26 & 0.97 \\
\hline 17.26528 & 1.83 & 1.16 & 0.86 & 0.31 & 3.74 & 2.79 & 0.86 & 11.63 & 8.67 & 2.68 \\
\hline 16.81444 & 2.08 & 1.27 & 0.88 & 0.29 & 3.60 & 2.50 & 0.71 & 11.22 & 7.76 & 2.20 \\
\hline Plume av. & & & & & $4.37 \pm 0.76$ & $2.82 \pm 0.34$ & $0.75 \pm 0.24$ & $13.6 \pm 2.4$ & $8.8 \pm 1.0$ & $2.3 \pm 0.7$ \\
\hline
\end{tabular}

Table 7. Emission factors EI for equivalent BC mass; data were calculated from absorption coefficient $\left(\sigma_{\text {ap }}\right)$ measurements according to $\mathrm{BC}_{e}=\sigma_{\mathrm{ap}} / b_{\mathrm{ap}}$ with $\left.b_{\mathrm{ap}}=8 \mathrm{~m}^{2} \mathrm{~g}^{-1}\right)$, standard deviations are: $\mathrm{sd}\left(\Delta \mathrm{CO}_{2}\right)=0.4 \mathrm{ppm}$, rel. $\mathrm{sd}\left(\mathrm{BC}_{e}\right)=0.25$.

\begin{tabular}{cccccc}
\hline UTC dec. time & $\begin{array}{c}\Delta \mathrm{CO}_{2} \\
\mathrm{ppm}\end{array}$ & $\begin{array}{c}\mathrm{BC}_{e} \\
\mu \mathrm{g} \mathrm{sm}^{-3}\end{array}$ & $\begin{array}{c}\mathrm{BC}_{e} / \mathrm{CO}_{2} \\
\mu \mathrm{g}\left(\mathrm{sm}^{3} \mathrm{ppm}\right)^{-1}\end{array}$ & $\begin{array}{c}\mathrm{EI}_{\mathrm{BC}} \\
\mathrm{mg} \mathrm{BC}_{e}\left(\mathrm{kgCO}_{2}\right)^{-1}\end{array}$ & $\begin{array}{c}\mathrm{EI}_{\mathrm{BC}} \\
\mathrm{mg} \mathrm{BC}_{e}(\mathrm{kgfuel})\end{array}$ \\
\hline 17.55667 & 112.7 & 11.73 & 0.083 & 49 & 153 \\
17.41472 & 68.5 & 8.65 & 0.101 & 60 & 185 \\
17.55528 & 56.2 & 5.98 & 0.085 & 50 & 156 \\
17.55556 & 55.1 & 5.69 & 0.083 & 49 & 151 \\
16.93806 & 35.8 & 3.61 & 0.081 & 48 & 148 \\
17.41639 & 24.46 & 1.75 & 0.057 & 34 & 105 \\
17.5525 & 21.6 & 3.45 & 0.128 & 75 & 234 \\
17.41694 & 20.7 & 3.51 & 0.136 & 80 & 249 \\
17.55361 & 20.1 & 2.54 & 0.101 & 60 & 186 \\
16.72083 & 15.1 & 1.79 & 0.095 & 56 & 174 \\
Plume average & & & $0.095 \pm 0.023$ & $56 \pm 14$ & $174 \pm 43$ \\
\hline
\end{tabular}

\subsubsection{Size distribution}

Particle number and $\mathrm{BC}$ mass emission indices are required for the calculation of particulate matter emitted from global shipping. Potential climate impacts on the Earth's radiation budget are linked primarily to particle size by means of activation of exhaust particles to cloud condensation nuclei in ship tracks (Hobbs et al., 2000; Dusek et al., 2006). In our studies, the entire particle size distribution was probed by a combination of CPC, DMA, and optical particle spectrometers. Except the DMA, all instruments operated at a time resolution $<5 \mathrm{~s}$ which is required for ship plume studies. During the closest plume encounters at the end of the plume study (see Fig. 7), however, a series of peaks was sampled which permitted the analysis of the DMA mobility spectrum at least in the size range with $D_{p}>0.03 \mu \mathrm{m}$. At smaller sizes the instrument suffered from sampling statistics at such short sequences. A snapshot of the particle size distribution in a very young ship plume $(t<300 \mathrm{~s})$ is plotted in Fig. 11. The exhaust particle mode inside the ship plume exceeded the background aerosol in the size range up to $0.2 \mu \mathrm{m}$. For particles larger than this range no deviation from the background aerosol was found. This observation matches the findings reported from the MAST experiment (Frick and Hoppel, 2000; Hobbs et al., 2000).

Because of the short duration of single plume encounters, the size distribution analysis requires a different approach. Using three CPC partially equipped with diffusion screen separators (Feldpausch et al., 2005) and the PCASP, a bimodal log-normal size distribution can be fitted to the measured data according to the following scheme which is a simplified version of Fiebig's data inversion algorithm (Fiebig et al., 2005): 
(i.) The bi-modal log-normal size distribution is expressed as

$$
\begin{aligned}
& \frac{d N}{d \log D_{p}}\left(D_{p}\right)=\sum_{i=1}^{2} \frac{N_{i}}{\sqrt{2 \pi} \log \left(\mathrm{GSD}_{i}\right)} \exp \\
& {\left[-\frac{1}{2} \frac{\left(\log \left(D_{p}\right)-\log \left(\mathrm{CMD}_{i}\right)\right)^{2}}{\log \left(\mathrm{GSD}_{i}\right)^{2}}\right]}
\end{aligned}
$$

with the modal parameters number concentration $\mathrm{N}_{i}$, count median diameter CMD, and geometric standard deviation GSD.

(ii.) Each CPC is operated with a specific cut-off characteristic which is represented as the normalised transfer function $\operatorname{TrCPC}_{i}\left(D_{p}\right)$ (Feldpausch et al., 2005). Integrating the normalised transfer function of CPC \# $i$ times the size distribution $\mathrm{dN} / \mathrm{d} \log D_{p}$ over the particle diameter interval [0, $\infty$ ] yields the total number of particles detected by the instrument:

$$
\int_{D_{p}=0}^{D_{p}=\infty} \operatorname{TrCPC}_{i}\left(D_{p}\right) \frac{d N}{d \log D_{p}}\left(D_{p}\right) d \log D_{p}=N_{i}
$$

A similar equation holds for each PCASP channel \# $j$ (Fiebig et al., 2005), i.e.

$$
\int_{D_{p}=0}^{D_{p}=\infty} \operatorname{TrPCASP}_{j}\left(D_{p}\right) \frac{d N}{d \log D_{p}}\left(D_{p}\right) d \log D_{p}=N_{j}
$$

(iii.) Using three CPC configurations and PCASP channels \#1-\#5 grouped as [\#1,\#2] and [\#3, \#4, \#5] defines a set of 5 equations which have to be solved simultaneously for the fitted size distribution $\mathrm{dN} / \mathrm{d} \log D_{p}$.

Figure 12 shows the result for plume encounters at $700 \mathrm{~s}$, $900 \mathrm{~s}$ and $1600 \mathrm{~s}$ plume age. The dashed line represents the marine aerosol outside of ship plumes. Modal parameters of the size distributions are compiled in Table 8. As is discussed in detail by Hobbs et al. (2000) the cloud residue mode at modal diameters of $200 \mathrm{~nm}$ contains the fraction of the marine aerosol which becomes activated for the formation of marine clouds. The local minimum between the residue mode and the Aitken mode indicates the minimum size of the background aerosol that was activated as CCN.

The combustion mode particles are observed in the same size range as the marine cloud residues. Furthermore, detailed studies on the $\mathrm{CCN}$ activation of combustion particles have demonstrated the strong impact of a sulphate coating on the $\mathrm{CCN}$ activation of carbonaceous particles on an observational basis (Petzold et al., 2005). The average size of combustion particles from ship engines combined with the large fraction of sulphate in aerosol mass underpins the key role of the combustion mode particles in ship track formation.

\section{Discussion}

As was discussed in Sect. 2.3, a ratio of $\operatorname{EX}(t)$ to $\Delta \mathrm{CO}_{2}$ $(t)$ independent of plume age $t$ indicates a chemically inert exhaust component EX which is diluted during plume

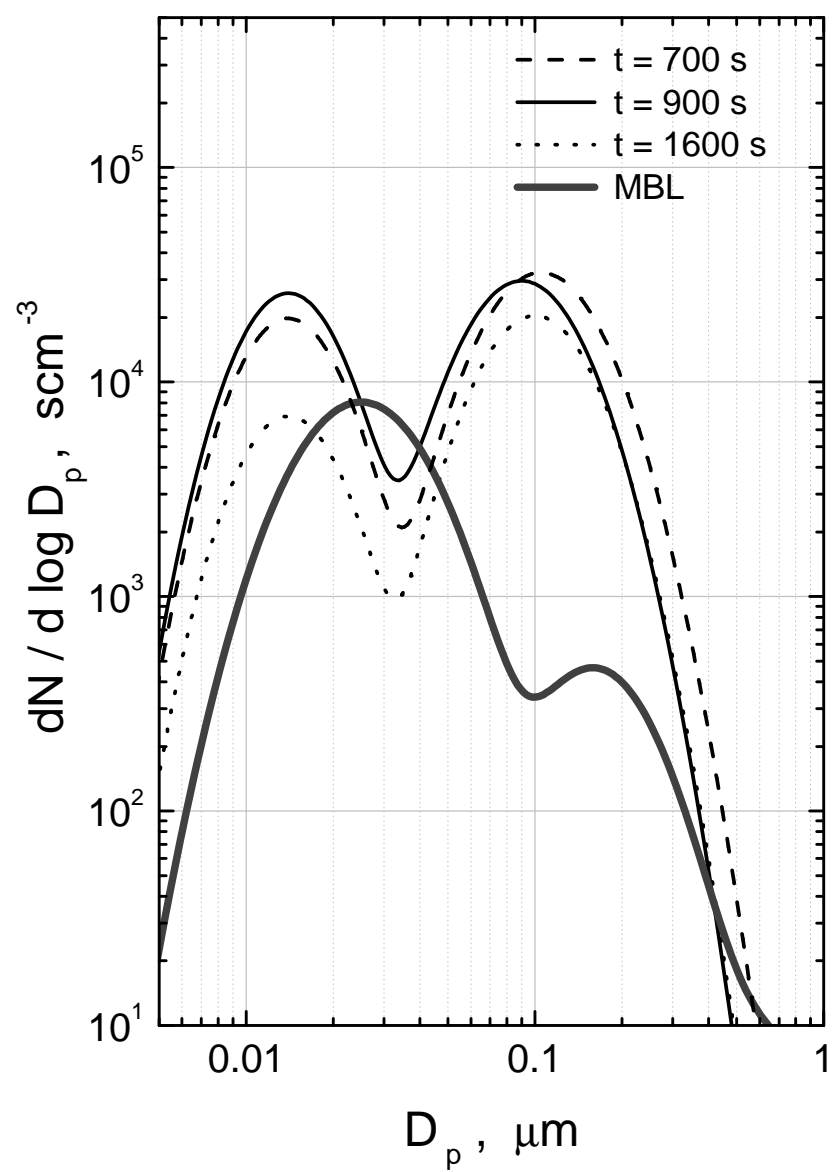

Fig. 12. Particle size distributions at various plume ages shown together with a typical size distribution in the clean marine background air. The MBL aerosol mode at a modal diameter of $200 \mathrm{~nm}$ corresponds to the cloud residue mode (see text for explanation).

expansion by processes similar to $\Delta \mathrm{CO}_{2}$ emitted from the engine. In Fig. 13, characteristic aerosol properties of nucleation mode, Aitken mode and non-volatile Aitken mode particles are plotted as function of plume age. In the top panel, the ratio of total aerosol number density $\mathrm{N}_{D>4 \mathrm{~nm}}$ to Aitken mode aerosol number density $\mathrm{N}_{D>13} \mathrm{~nm}$ reflects the abundance of nucleation mode particles in the total aerosol. The ratio of 1.0 indicates the absence of nucleation mode particles since $\mathrm{N}_{D>4 \mathrm{~nm}}=\mathrm{N}_{D>13 \mathrm{~nm}}$. Inside the plume for plume ages $t<1000 \mathrm{~s}$ the ratio is slightly larger than 1.0 , but still decreasing with age. The value of 1.0 is reached at about $t=1000 \mathrm{~s}$. Nucleation mode particles which have formed in the expanding and cooling plume from emitted gaseous precursors have vanished after about $1000 \mathrm{~s}$, presumably due to coagulation with Aitken and accumulation mode particles. The abundance of nucleation mode particles in raw emission however is unknown since the measured particle number densities exceeded the upper detection limit of the instruments. We only can state that this ratio is beyond the value of 10 . 
Table 8. Aerosol size properties for marine diesel engine exhaust particles in ship plumes; particle diameters refer to dry conditions.

\begin{tabular}{|c|c|c|c|c|c|c|c|c|}
\hline UTC & $\Delta \mathrm{CO} \mathrm{ppm}$ & $\mathrm{N}_{\text {TOTAL }}^{+)} \mathrm{scm}^{-3}$ & $\mathrm{~N}_{\mathrm{NUC}}^{\#)} \mathrm{scm}^{-3}$ & $\mathrm{CMD} \mu \mathrm{m}$ & GSD & $\mathrm{N}_{\mathrm{ACC}}^{\#)} \mathrm{scm}^{-3}$ & $\mathrm{CMD} \mu \mathrm{m}$ & GSD \\
\hline Cloud residues & 0.0 & & & & & & 0.160 & 1.5 \\
\hline $16.75083 \# 2$ & 2.632 & 21300 & 8000 & 0.014 & 1.45 & 15000 & 0.105 & 1.53 \\
\hline $17.07389 \# 7$ & 2.514 & 23800 & 10500 & 0.014 & 1.45 & 13500 & 0.090 & 1.52 \\
\hline $17.26528 \# 10$ & 1.825 & 11500 & 2800 & 0.014 & 1.45 & 9000 & 0.100 & 1.5 \\
\hline
\end{tabular}

+) value measured by $\mathrm{N}_{4} \mathrm{CPC}$.

\#) values obtained from log-normal fitting.

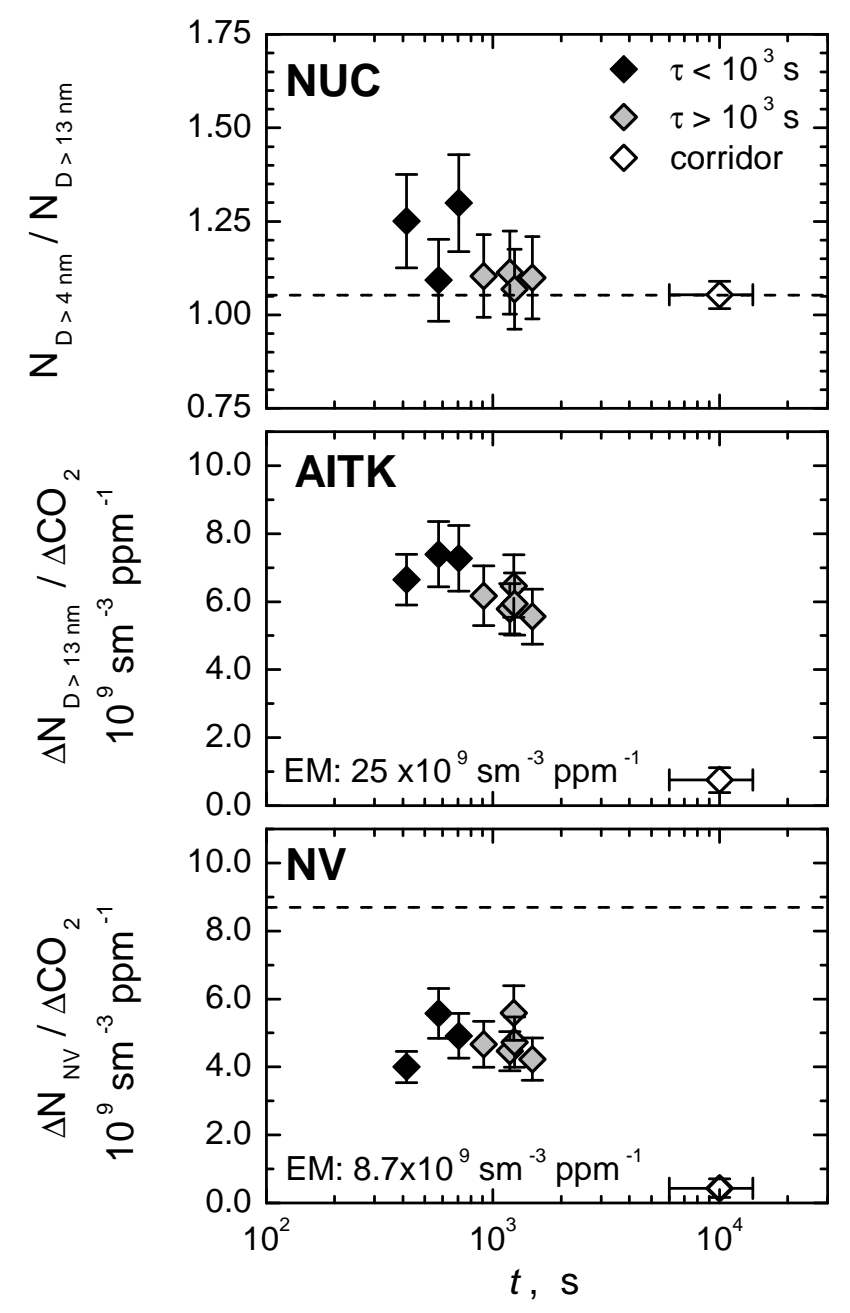

Fig. 13. Evolution of fraction of nucleation mode aerosol $\left(\mathrm{N}_{D>4 \mathrm{~nm}} / \mathrm{N}_{D>13 \mathrm{~nm}}\right.$; top panel), of Aitken mode aerosol $\left(\Delta \mathrm{N}_{D>13 \mathrm{~nm}} / \Delta \mathrm{CO}_{2}\right.$; mid panel), and of non-volatile Aitken mode aerosol ( $\Delta \mathrm{N}_{\text {nonvol }} / \Delta \mathrm{CO}_{2}$; bottom panel) during plume expansion and dispersion: symbols indicate the plume age regime, values for emission conditions (EM) are added to the Aitken mode and nonvolatile mode panel.
The processing of Aitken mode particles follows different paths for the total aerosol including secondary volatile particles on one hand and the non-volatile combustion particles on the other hand. Referring to Sect. 3.1, we know from the emission studies that volatile and non-volatile particles can be related to different size ranges with modal diameters of $<0.02 \mu \mathrm{m}$ for the total Aitken mode and $\cong 0.05 \mu \mathrm{m}$ for the combustion particles mode, respectively. The single plume study now yields that the excess Aitken mode number density per $\Delta \mathrm{CO}_{2}$ decreases in the plume with increasing plume age, which indicates ongoing particle loss from the Aitken mode during plume expansion, see the middle panel of Fig. 13. In contrast, this is not the case for the number density of nonvolatile particles, as is shown in the bottom panel of Fig. 13. Relating the respective ratios for fresh emissions to the plume observations, the number of Aitken mode particles per $\mathrm{CO}_{2}$ is reduced by a factor of three from fresh exhaust to plume, while the number of non-volatile particles is reduced by an approximate factor of 1.5. Respective data are compiled in Table 6.

Coagulation loss of volatile particles during plume expansion may be inferred also from the analysis of the fraction of non-volatile particles of the total Aitken mode during plume expansion. For emission conditions, the fraction of non-volatile particles of the total exhaust aerosol is 0.34 , see Table 2 for details. In a young ship plume with plume ages of $10^{3}-10^{4} \mathrm{~s}$, the average fraction with respect to all plume encounters is $0.65 \pm 0.10$ (Table 6). In the ship corridor study, an average fraction of $0.72 \pm 0.05$ was found for plumes older than $10^{4} \mathrm{~s}$. Finally, the respective fraction for the marine boundary layer aerosol outside of ship plumes is $0.82 \pm 0.03$. The set of values clearly shows a decrease of volatile particles compared to non-volatile particles during aerosol processing.

Combining these observations with the close agreement of the BC mass emission indices from emission testing and from the plume study, the number density of the non-volatile aerosol which is dominated by larger $(\mathrm{CMD} \cong 0.08 \mu \mathrm{m})$ nonvolatile, carbonaceous combustion particles and the $\mathrm{BC}$ mass can indeed be viewed as aerosol properties conserved during plume expansion and dilution. The total Aitken 
mode aerosol number density which is by far dominated by small $(\mathrm{CMD}=0.015 \mu \mathrm{m})$ secondary volatile particles is subject to strong particle coagulation, resulting in a decreasing number density during plume ageing. Since the ratio $\mathrm{N}_{D>13 \mathrm{~nm}} / \Delta \mathrm{CO}_{2}$ still decreases at plume ages $>1000 \mathrm{~s}$, the coagulation process is still ongoing. Concluding, "true" particle number emission indices for marine diesel engines operating on cruising ship can only be reported for the nonvolatile fraction of the exhaust aerosol. The total Aitken mode aerosol has to be treated by an effective emission indices approach which has to take coagulation loss of volatile particles into account.

Although CCN were not measured during this experiment, the exhaust particle fraction relevant for potential climate effects of shipping can be reduced to the larger combustion particle mode which falls into the size range of potential CCN. Following Shinha et al. (2003) and Hobbs et al. (2000), the ratio of $\mathrm{CCN}$ to $\mathrm{CN}$ varies from 18 $19 \%$. Applying this ratio to the plume averaged emission index for non-volatile particles of the exhaust aerosol $\left(\mathrm{EI}_{N V}=8.8 \pm 1.0 \times 10^{15}(\mathrm{~kg} \text { fuel })^{-1}\right)$ would yield an average $\mathrm{CCN}$ emission index of $1.66 \times 10^{15}(\mathrm{~kg} \text { fuel })^{-1}$. The respective average emission factor for accumulation mode particles $\left(D_{p}>0.1 \mu \mathrm{m}\right)$ is $2.3 \pm 0.7 \times 10^{15}(\mathrm{~kg} \text { fuel })^{-1}$ which indicates that all accumulation mode particles will be activated for cloud drop formation. From direct $\mathrm{CCN}$ measurements, Shinha et al. (2003) reported values of $0.76-1.1 \times 10^{15}(\mathrm{~kg}$ fuel $)^{-1}$.

The decay of the particulate matter-related signal of ship emissions during plume expansion and dilution provides an upper estimate for the average plume life time. In Fig. 14, the ratio of excess particles from ship emissions to marine boundary layer Aitken mode particles is plotted as a function of plume age. Experimental data from the plume encounters are plotted along with a dilution function given by a Gaussian plume model shown as a dashed line. The model input $\alpha=0.74, \beta=0.70, \Delta \mathrm{N}(t=0)=2.5 \times 10^{8} \mathrm{~cm}^{-3}$, and $\mathrm{N}_{\mathrm{MBL}}=900 \mathrm{~cm}^{-3}$ used to compute the dilution function reflected the conditions for 30 July 2004. Assuming a conservative range of threshold values of $\Delta \mathrm{N}_{\text {PLUME, min }}=[0.5-$ $0.75] \times \mathrm{N}_{\text {MBL }}$ which a ship plume must exceed for being identified as plume encounter, a plume life time of 7$10 \times 10^{4} \mathrm{~s}$ can be estimated from the Gaussian dilution function. During this time, a ship plume may be identified by the particle signal enhancement above the marine background aerosol. Turbulent mixing in the MBL will of course reduce the life time significantly. The presented upper estimate refers only to diffusive broadening of the plume.

\section{Conclusions}

In a combined study on particle emissions from marine diesel engines and their transformation in the dissolving ship plume, the main characteristics of particulate matter emit-

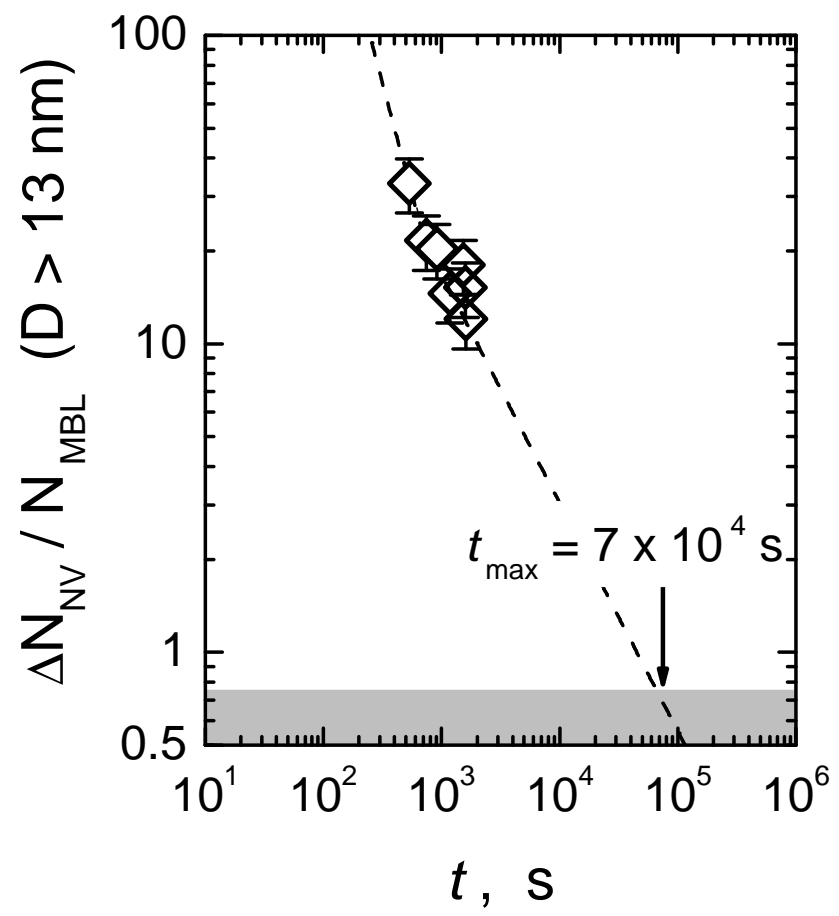

Fig. 14. Ship plume particle signature in terms of excess nonvolatile particles in the plume $\Delta \mathrm{N}_{\mathrm{NV}}$ to number of MBL particles $\mathrm{N}_{\mathrm{MBL}}$ as a function of plume age $t$; symbols indicate observational data while the dashed line gives the result of the Gaussian plume model. The maximum detectable plume age of $7 \times 10^{4} \mathrm{~s}$ corresponds to the plume age for which the plume signal $\Delta N_{N V}$ becomes indistinguishable from a varying MBL aerosol at $\Delta \mathrm{N}_{\mathrm{NV}}$ $\leq 0.75 \mathrm{~N}_{\mathrm{MBL}}$.

ted from shipping were investigated. Test bed studies using a serial marine diesel engine provided microphysical and chemical properties of freshly emitted particles. These data served as input information for the investigation of dissolving ship plumes during airborne measurements in the English Channel and in a single ship plume generated by a specific source vessel. A Gaussian plume dispersion model introduced by von Glasow et al. (2003) in combination with the observations from emission studies and plume studies yields a consistent picture of particle transformation processes from emission from a ship engine to atmospheric processing in the marine boundary layer during plume expansion. The results were used for the determination of emission indices of particulate matter from ships and for the estimation of life times of ship exhaust particles in the marine boundary layer. Obtained values for black carbon mass and particle number agree well with data reported in the literature. Ship plume lifetimes of $<10^{5} \mathrm{~s}$ were estimated from the ship plume signals and the plume dispersion model. For the first time, emission indices for the non-volatile particle fraction are reported which form the most relevant particle fraction in terms of aerosol - cloud interaction during ship track formation. 
Acknowledgements. This study would not have been possible without the close collaboration of A. P. Moller - Maersk A/S which is gratefully acknowledged by all authors. Part of this work was funded by the EC within the Integrated Projects HERCULES (Contract No. TIP3-CT-2003-506676) and QUANTIFY (Contract No. 003893 GOCE), and within the German Helmholtz Association Research Group SeaKLIM. We are grateful to Axel Lauer (DLR) and to one of the anonymous reviewers for helpful comments and suggestions on the manuscript, and to Horst Fischer (MPI-C Mainz) for supporting the $\mathrm{CO}_{2}$ data analysis. We also acknowledge the support of the study by the DLR flight crew and the assistance during the measurements by Michael Lichtenstern, Andreas Minikin and Philipp Feldpausch from DLR.

Edited by: K. Carslaw

\section{References}

Andreae, M. O. and Gelencser, A.: Black carbon or brown carbon?, Atmos. Chem. Phys., 6, 3131-3148, 2006,

http://www.atmos-chem-phys.net/6/3131/2006/.

Beirle, S., Platt, U., von Glasow, R., Wenig, M., and Wagner, T.: Estimate of nitrogen oxide emissions from shipping by satellite remote sensing, Geophys. Res. Lett., 31, L18102, doi:10.1029/2004GL020312, 2004.

Bond, T. C., Anderson, T. L., and Campbell, D.: Calibration and intercomparison of filter-based measurements of visible light absorption by aerosols, Aerosol Sci. Technol., 30, 582-600, 1999.

Bond, T. C. and Bergstrom, R. W.: Light absorption by carbonaceous particles: An investigative review, Aerosol Sci. Technol., 40, 27-67, 2006.

Burtscher, H., Baltensperger, U., Bukowiecki, N., Cohn, P., Hüglin, C., Mohr, M., Matter, M., Nyeki, S., Schmatloch, V., Streit, N., and Weingartner, E.: Separation of volatile and non-volatile aerosol fractions by thermodesorption: Instrument development and applications, J. Aerosol Sci., 32, 427-442, 2001.

Capaldo, K., Corbett, J. J., Kasibhatla, P., Fischbeck, P. S. and Pandis, S. N.: Effects of ship emissions on sulfur cycling and radiative climate forcing over the ocean, Nature, 400, 743-746, 1999.

Chen, G., Huey, G., Trainer, M., et al.: An investigation of the chemistry of ship emission plumes during ITCT 2002, J. Geophys. Res. 110, doi:10.1029/2004JD005236, 2005.

Cooper, D. A.: Exhaust emissions from ships at berth, Atmos. Environ., 37, 3817-3830, 2003.

Corbett, J. J.: New directions: Designing ship emissions and impacts research to inform both science and policy, Atmos. Environ., 37, 4719-4721, 2003.

Corbett, J. J. and Fischbeck, P. S.: Emissions from ships, Science 278, 3723-3731, 1997.

Devasthale, A., Krüger, O., and Gragl, H.: Impact of ship emissions n cloud properties over coastal areas, Geophys. Res. Lett., 33, L02811, doi:10.1029/2005GL024470, 2006.

Durkee, P. A., Noone, K. J., and Bluth, R. T.: The Monterey Area ship track experiment, J. Atmos. Sci., 57, 2523-2541, 2000a.

Durkee, P. A., Chartier, R. E., Brown, A., Trehubenko, E. J., Rogerson, S. D., Skupniewicz, C., Nielsen, K. E., Platnick, S., and King, M. D.: Composite ship track characteristics, J. Atmos. Sci., 57, 2542-2553, 2000b.
Dusek, U., Frank, G. P., Hildebrandt, L., Curtius, J., Schneider, J., Walter, S., Chand, D., Drewnick, F., Hungs, S., Jung, D., Borrmann, S., and Andreae, M. O.: Size matters more than chemistry for cloud-nucleating ability of aerosol particles, Science, 312, 1375-1378, 2006.

Endresen, Ø., Sørgård, E., Sundet, J. K., Dalsøren, S. B., Isaksen, I. S. A., Berglen, T. F., and Gravir, G.: Emission from international sea transportation and environmental impact, J. Geophys. Res. 108, 4560, doi:10.1029/2002JD002898, 2003.

Eyring V., Köhler, H. W., van Aardenne, J., and Lauer, A.: Emissions from international shipping: 1. The last 50 years, J. Geophys. Res., 110, D17305, doi:10.1029/2004JD005619, 2005a.

Eyring V., Köhler, H. W., Lauer, A., and Lemper, B.: Emissions from international shipping: 2. Impact of future technologies on scenarios until 2050, J. Geophys. Res., 110, D17306, doi:10.1029/2004JD005620, 2005b.

Eyring, V., Stevenson, D. S., Lauer, A., et al.: Multi-model simulations of the impact of international shipping on Atmospheric Chemistry and Climate in 2000 and 2030 Atmos. Chem. Phys., 7, 757-780, 2007.

Feldpausch, P., Fiebig, M., Fritzsche, L., and Petzold, A.: Measurement of ultrafine aerosol size distributions by a combination of diffusion screen separators and condensation particle counters, J. Aerosol Sci., 37, 577-597, doi:10.1016/j.jaerosci.2005.04.009, 2006.

Fiebig, M., Stein, C., Schröder, F., Feldpausch, P., and Petzold, A.: Inversion of data containing information on the aerosol particle size distribution using multiple instruments, J. Aerosol Sci.,36, 1353-1372, 2005.

Frick, G. M. and Hoppel, W. A.: Airship measurements of ship's exhaust plumes and their effect on marine boundary layer clouds, J. Atmos. Sci., 57, 2625-2648, 2000.

Gopalakrishnan, V., Pawar, S. D., Siinggh, D., and Kamra, A. K.: Intermediate ion formation in ship's exhaust, Geophys. Res. Lett., 32, L11806, doi:10.1029/2005GL022613, 2005.

Hobbs, P. V., Garrett, T. J., Ferek, R. J., Strader, S. R., Hegg, D. A., Frick, G. M., Hoppel, W. A., Gasparovic, R. F., Russell, L. M., Johnson, D. W., O’Dowd, C., Durkee, P. A., Nielsen, K. E., and Innis, G.: Emissions from ships with respect to their effects on cloud, J. Atmos. Sci., 57, 2570-2590, 2000.

Kasper, A., Aufdenblatten, S., Forss, A., Mohr, M., and Burtscher, H.: Particulate emissions from a low-speed marine diesel engine, Aerosol Sci. Technol., 41, 24-32, 2007.

Köhler, H. W.: Worldwide $\mathrm{NO}_{\mathrm{x}}$ emissions from merchant shipping, paper presented at 24th Annual Marine Propulsion Conference, 10-11 April, Copenhagen, Denmark, 2002.

Köhler, H. W.: $\mathrm{NO}_{\mathrm{x}}$ emissions from ocean-going ships: Calculation and evaluation, paper presented at Spring Technical Conference, Internal Combust. Engine Div., Am. Soc. of Automotive Eng., Salzburg, Austria, 11-14 May, 2003.

Lawrence, M. G. and Crutzen, P. J.: Influence of $\mathrm{NO}_{\mathrm{x}}$ emissions from ships on tropospheric photochemistry and climate, Nature, 402, 167-170, 1999.

Lyyränen, J., Jokiniemi, J., Kauppinen, E. I., and Joutsensaari, J.: Aerosol characterisation in medium-speed diesel engines operating with heavy fuel oils, J. Aerosol Sci., 30, 771-784, 1999.

Noone K. J., Öström, E., Ferek, R. J., et al.: A case study of ships forming and not forming tracks in moderately polluted clouds, J. Atmos. Sci., 57, 2729-2747, 2000. 
Osborne, S. O., Johnson, D. W., Bower, K. N., and Wood, R.: Modification of the aerosol size distribution within exhaust plumes produced by diesel-powered ships, J. Geophys. Res., 106, 98279842, 2001.

Petzold, A., Feldpausch, P., Fritzsche, L., Minikin, A., Lauer, P., Kurok, C., and Bauer, H.: Particle emissions from ship engines, J. Aerosol Sci., Abstracts of the European Aerosol Conference, S1095-S1096, 2004.

Petzold, A. and Schönlinner, M.: Multi-angle absorption photometry - a new method for the measurement of aerosol light absorption and atmospheric black carbon, J. Aerosol Sci., 35, 421-441, 2004.

Petzold, A., Gysel, M. , Vancassel, X., Hitzenberger, R., Puxbaum, H., Vrochticky, S., Weingartner, E. , Baltensperger, U., and Mirabel, P.: On the effects of organic matter and sulphurcontaining compounds on the CCN activation of combustion particles, Atmos. Chem. Phys., 5, 3187-3203, 2005, http://www.atmos-chem-phys.net/5/3187/2005/.

Petzold, A., Weinzierl, B., Fiebig, M., Lichtenstern, M., Lauer, P., Gurk, C., Franke, K., and Weingartner, E.: Particle Emissions from Ship Engines: Emission Properties and Transformation in the Marine Boundary Layer, Proceedings of the International Conference on Transport, Atmosphere and Climate, Oxford, June 2006, TAC Extended Abstracts, 2007.

Petzold, A., Weinzierl, B., Huntrieser, H., Stohl, A., Real, E., Cozic, J., Fiebig, M., Hendricks, J., Lauer, A., Law, K., Minikin, A., Roiger, A., Schlager, H., and Weingartner, E.: Perturbation of European Free Troposphere Aerosol by North American Forest Fire Plumes during the ICARTT-ITOP Experiment in Summer 2004, Atmos. Chem. Phys., 7, 5105-5127, 2007, http://www.atmos-chem-phys.net/7/5105/2007/.

Schlager, H., Baumann, R., Lichtenstern, M., Petzold, A., Arnold, F. , Speidel, M., Gurk, C., and Fischer, H.: Aircraft-based Trace Gas Measurements in a Primary European Ship Corridor, Proceedings of the International Conference on Transport, Atmosphere and Climate, Oxford, June 2006, TAC Extended Abstracts, 2007
Schmid, H., Laskus, L., Abraham, H. J., Baltensperger, U., Lavanchy, V., Bizjak, M., Burba, P., Cachier, H., Crow, D., Chow, J., et al.: Results of the "carbon conference" international aerosol carbon round robin test stage I., Atmos. Environ., 35, 21112121, 2001.

Schröder, F. P. and Ström, J.: Aircraft measurements of sub micrometer aerosol particles $(>7 \mathrm{~nm})$ in the midlatitude free troposphere and tropopause region, Atmos. Res., 44, 333-356, 1997.

Sinha, P., Hobbs, P. V., Yokelson, R. J., Christian, T. J., Kirchstetter, T. W., and Bruintjes, R.: Emission of trace gases and particles from two ships in the southern Atlantic Ocean, Atmos. Environ., 37, 2139-2148, 2003.

Song, C. H., Chen, G., Hanna, S. R., Crawford, J., Davis, D. D.: Dispersion and chemical evolution of ship plumes in the marine boundary layer: Investigation of $\mathrm{O}_{3} / \mathrm{NO}_{\mathrm{y}} / \mathrm{HO}_{\mathrm{x}}$ chemistry, J. Geophys. Res. 108, 4143, doi:10.1029/2002JD002216, 2003.

Ulrich, E. W.: Entwicklung eines thermografischen Verfahrens zur Analyse von Dieselpartikelemissionen (Development of a thermographic method for the analysis of diesel particulate matter), PhD Thesis, Technical University of Berlin, Berlin 1994.

VDI Guideline 2465 - 2: Measurement of soot (ambient air) Thermographical determination of elemental carbon after thermal desorption of organic carbon, VDI/DIN - Reinhaltung der Luft, Beuth, Berlin, 2005.

von Glasow, R., Lawrence, M. G., Sander, R., and Crutzen, P. J.: Modelling the chemical effects of ship exhaust in the cloud-free marine boundary layer, Atmos. Chem. Phys., 3, 233-250, 2003, http://www.atmos-chem-phys.net/3/233/2003/.

Williams, E., Lerner, B., Quinn, P., and Bates, T.: Measurements of gas and particle emissions from commercial marine vessels, Eos Trans. AGU, 86(52), Fall Meet. Suppl., Abstract A51E-0130, 2005. 